ARTICLE

DOI: $10.1038 /$ s41467-018-04255-z

\title{
A self-destructive nanosweeper that captures and clears amyloid $\beta$-peptides
}

Qiang Luo ${ }^{1,2}$, Yao-Xin Lin'2,3,4, Pei-Pei Yang ${ }^{2}$, Yi Wang ${ }^{2,3}$, Guo-Bin $\mathrm{Qi}^{2}$, Zeng-Ying Qiao², Bing-Nan Li,2, Kuo Zhang ${ }^{1,2}$, Jing-Ping Zhang ${ }^{1}$, Lei Wang ${ }^{2} \&$ Hao Wang 2,3

Cerebral amyloid $\beta$-peptide (A $\beta$ ) accumulation resulting from an imbalance between $A \beta$ production and clearance is one of the most important causes in the formation of Alzheimer's disease (AD). In order to preserve the maintenance of $A \beta$ homeostasis and have a notable $A D$ therapy, achieving a method to clear up $A \beta$ plaques becomes an emerging task. Herein, we describe a self-destructive nanosweeper based on multifunctional peptide-polymers that is capable of capturing and clearing $A \beta$ for the effective treatment of $A D$. The nanosweeper recognize and bind $A \beta$ via co-assembly through hydrogen bonding interactions. The $A \beta$ loaded nanosweeper enters cells and upregulates autophagy thus promoting the degradation of $A \beta$. As a result, the nanosweeper decreases the cytotoxicity of $A \beta$ and rescues memory deficits of $A D$ transgenic mice. We believe that this resourceful and synergistic approach has valuable potential as an $A D$ treatment strategy.

\footnotetext{
${ }^{1}$ Faculty of Chemistry, Northeast Normal University, 130024 Changchun, China. ${ }^{2}$ CAS Center for Excellence in Nanoscience, CAS Key Laboratory for Biomedical Effects of Nanomaterials and Nanosafety, National Center for Nanoscience and Technology (NCNST), 100190 Beijing, China. ${ }^{3}$ University of Chinese Academy of Sciences, 100049 Beijing, China. ${ }^{4}$ School of Pharmaceutical Sciences (Shenzhen), Sun Yat-sen University, Guangzhou 510006, China. These authors contributed equally: Qiang Luo, Yao-Xin Lin, Pei-Pei Yang. Correspondence and requests for materials should be addressed to J.-P.Z. (email: zhangjp162@nenu.edu.cn) or to L.W. (email: wanglei@nanoctr.cn) or to H.W. (email: wanghao@nanoctr.cn)
} 
A lzheimer's disease $(\mathrm{AD})$ has been considered the most pervasive neurodegenerative disorder, affecting a great number of humans worldwide $\mathrm{e}^{1-3}$. The emphatic pathological hallmarks of $\mathrm{AD}$ are extracellular deposits of selfassembled fibrils based on the amyloid $\beta$-peptide $(\mathrm{A} \beta)$ and intracellular neurofibrillary tangles containing hyperphosphorylated tau ${ }^{4-8}$. Over the past few decades, the trend in therapeutic methods for AD involved inhibiting the self-assembly of $A \beta$ into fibrils and thus the resultant deposition of $A \beta$. Intense research indicates that inhibitors, such as antibodies ${ }^{9}$, peptidebased nanomaterials ${ }^{10-12}$, small molecules ${ }^{13,14}$, and various nanoparticles ${ }^{15-17}$, can decelerate the aggregation of $A \beta$. However, the recent failure of clinical trials based on bapineuzumab ${ }^{18}$ and solanezumab ${ }^{19}$ suggests that there is still a long way to go in treatment of $\mathrm{AD}$ against $\mathrm{A} \beta^{20,21}$. It has been accepted, when considering $\mathrm{AD}$ therapeutics, that the clearance of $\mathrm{A} \beta$ is the essential component in the maintenance of $A \beta$ homeostasis.

Autophagy, the way by which cells degrade their own metabolites, may be applied for $A \beta$ clearance. Indeed, the dysfunction of the autophagy-lysosome system leads to the accumulation of $A \beta^{22,23}$. It is beneficial for the enhancement of $A \beta$ clearance that the induction of autophagy is appropriately elevated, giving rise to the distinct implication of autophagy as a therapeutic strat$e^{23-25}$. However, because $A \beta$ generated from amyloid precursor protein (APP) in endosomes is recycled to the cell surfaces and usually aggregates and deposits outside the cell while autophagic degradation occurs intracellularly, the concept of $A \beta$ clearing by autophagy is contradictory.

Herein, we design a nanosweeper with the goal of effectively degrading extracellular $A \beta$, and find that it not only captures extracellular $A \beta$ and carries $A \beta$ into cells, but it also upregulates cellular autophagy and digestes $A \beta$. The nanosweeper is composed of a cationic chitosan (CS) core decorated with PEGylated-GKLVFF (designated as $\mathrm{K}$ ) and Beclin-1
(TGFQGSHWIHFTANFVNT, designated as B). KLVFF can recognize and co-assemble with $A \beta$ through hydrogen-bonding interactions. Beclin-1 can induce autophagy to degrade $A \beta$. The polyethylene glycol (PEG) increases the dispersity of the nanosweeper in water, providing the appropriate biocompatibility and stability. First, the nanosweeper captures and co-assembles with extracellular $A \beta$ specifically, inhibiting the formation of toxic $A \beta$ aggregates remarkably. Next, the nanosweeper preferentially delivers $A \beta$ into cells and activates autophagy within them to degrade $A \beta$, ultimately resulting in $A \beta$ clearance (Fig. 1). Results from in vitro and in vivo experiments confirms the nanosweeper's high-efficiency for $A \beta$ clearance. Among the A $\beta$-treated cells, the nanosweeper increases the cell viability from approximately 60 to 93\%. Furthermore, the insoluble $A \beta$ is decreased from 1539 to $914 \mathrm{ng} / \mathrm{mg}$, and soluble $\mathrm{A} \beta$ is decreased from 585 to $190 \mathrm{ng} / \mathrm{mg}$ in the brain of $\mathrm{AD}$ transgenic mice treated with the nanosweeper, leading to rescued memory deficits. This delicate nano-strategy can be a potential therapeutic approach in the treatment of AD.

\section{Results}

Preparation of the nanosweeper. A series of nanosweepers with various chemical compositions were established by changing the peptide ratios $^{26}$. There were two functional peptide analogs, a KLVFF peptide that could recognize and bind with $\mathrm{A} \beta_{42}{ }^{27,28}$, and a Beclin1 peptide that could significantly induce autophagy ${ }^{29,30}$. Both functional peptides were applied for linking with chitosan (CS) that was first modified by acrylate (acryl-CS). To control the hydrophobic/hydrophilic balance of the nanosweeper, PEG $_{368}$ was used to modify the $G$ residue of the GKLVFF peptide. As shown in Fig. 2a, the feed molar ratios of KLVFF (Supplementary Fig. 1) and Beclin-1 were adjusted to obtain polymers with various peptide ratios. The final products were designated as $M_{1}, M_{2}$, $M_{3}, M_{4}$, and $M_{5}$. The structures of acryl-CS and $M_{1-5}$ were

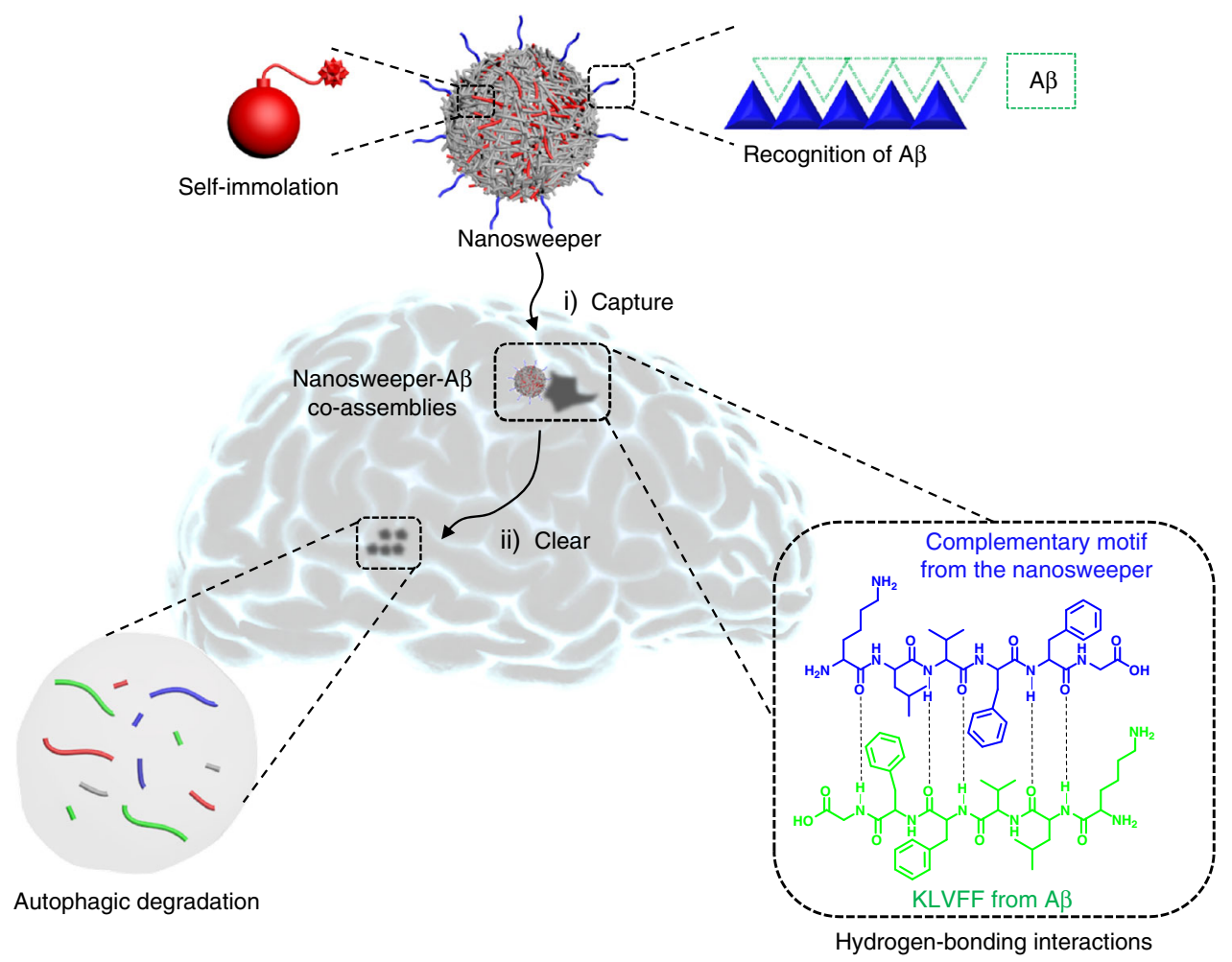

Fig. 1 The schematic illustration of the nanosweeper mechanism of action. The nanosweeper captures A $\beta$ by hydrogen-bonded co-assembly and internalizes a substantial amount into cells carrying $A \beta$. Then, the nanosweeper activates the cell's autophagic response, resulting in the degradation of $A \beta$ and the nanosweeper itself 
a

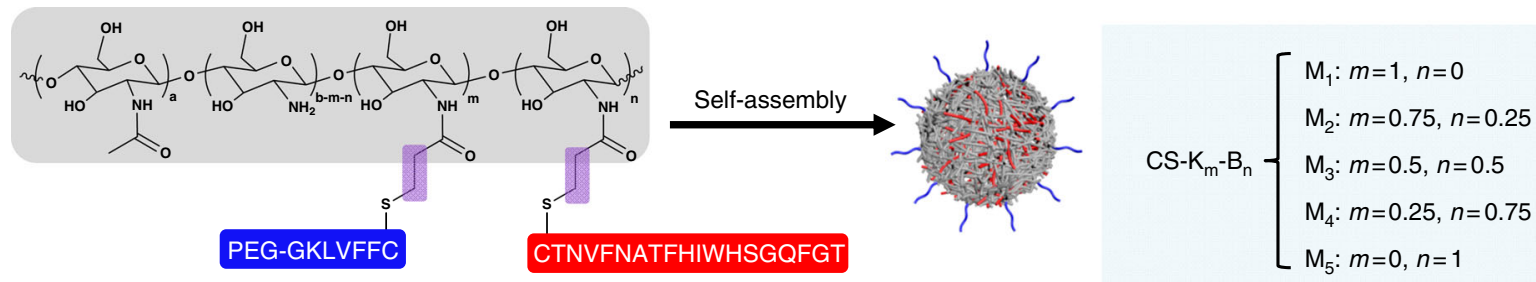

Molecular structure of nanosweeper

b

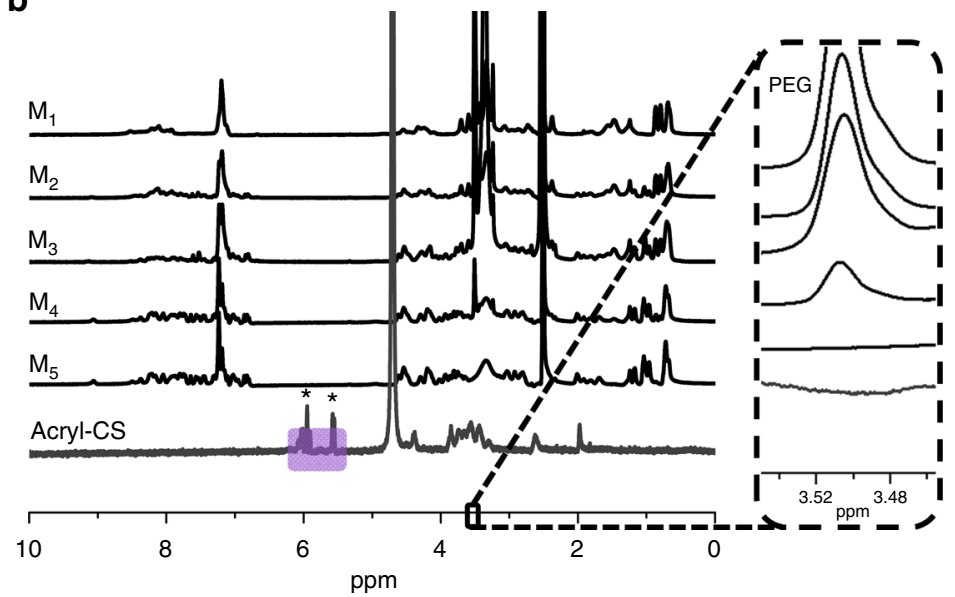

C

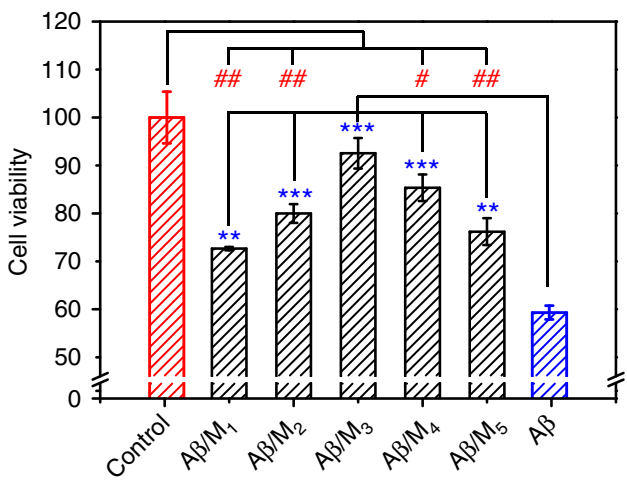

Fig. 2 The molecular structure and biological effect of $M_{3}$ in vitro. a Molecular structures of the multifunctional peptide-polymer $M_{1-5}$, $\mathrm{K}$ and $B$ were the abbreviation of HS-CFFVLKG-PEG (capture unit) and HS-CTNVFNATFHIWHSGQFGT (clearance unit), respectively. $\mathbf{b}$ The ${ }^{1} \mathrm{H}$ NMR of $\mathrm{M}_{1-5}$ in ${ }^{6} \mathrm{D}^{-D M S O}$ and acryl-CS in ${ }^{6} \mathrm{D}-\mathrm{H}_{2} \mathrm{O}$. c A $\beta$ cytotoxicity $(20 \mu \mathrm{M})$ to $\mathrm{N} 2 \mathrm{a}$ cells was reduced in the presence of $20 \mu \mathrm{g} \cdot \mathrm{mL}^{-1} \mathrm{M}_{1-5}$. Data are presented as mean \pm standard deviation (s.d.) $(n=3)$, analyzed by a Student's $t$-test. Statistical significance is indicated as ${ }^{\star} p<0.05,{ }^{\star \star} p<0.01$, and ${ }^{\star \star \star} p<0.001$, for comparison with A $\beta$

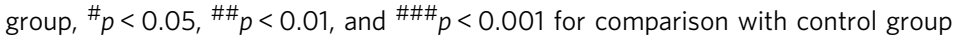

confirmed by ${ }^{1} \mathrm{H}$ NMR. As shown in Fig. 2b, the ${ }^{1} \mathrm{H}$ NMR spectrum of acryl-CS revealed acrylate double bonds at 5.8-6.3 ppm. However, the acrylate double bonds in the ${ }^{1} \mathrm{H}$ NMR of $\mathrm{M}_{1-5}$ disappeared entirely, indicating that the acrylate groups in acrylCS reacted completely with sulfhydrylated KLVFF and Beclin-1 peptide. The peaks at 6.7-8.5 in the spectra of $M_{2}, M_{3}, M_{4}$ and $M_{5}$ were typical Beclin-1 peaks ${ }^{30}$. Meanwhile, a characteristic PEG peak appeared at 3.4-3.6 in the ${ }^{1} \mathrm{H}$ NMR spectra of $\mathrm{M}_{1}, \mathrm{M}_{2}, \mathrm{M}_{3}$ and $\mathrm{M}_{4}$, but not in that of $\mathrm{M}_{5}$.

Biocompatibility and anti-A $\boldsymbol{\beta}$ toxicity of the nanosweeper. In order to investigate the biological effects of the nanosweeper, we first explored its biocompatibility by measuring cytotoxicity in the mouse neuroblastoma cell line N2a. Cells were cultured with $\mathrm{M}_{1-5}$ for $24 \mathrm{~h}$, and then assessed by CCK-8 assay. As shown in Supplementary Fig. 2, $\mathrm{M}_{1-5}$ at a concentration of $20 \mu \mathrm{g} \cdot \mathrm{mL}^{-1}$ showed good biocompatibility with approximate $100 \%$ viability, and so this concentration was utilized for further in vitro experiments. Next, to measure the anti-A $\beta$ toxicity of $\mathrm{M}_{1-5}$, we detected the cell viability of $\mathrm{N} 2 \mathrm{a}$ cells treated with $\mathrm{A} \beta_{42}(20 \mu \mathrm{M})$ in the absence or presence of $\mathrm{M}_{1-5}\left(20 \mu \mathrm{g} \cdot \mathrm{mL}^{-1}\right)$. As shown in Fig. $1 \mathrm{c}, \mathrm{A} \beta_{42}$ alone exhibited obvious toxicity (cell viability, 59.3\%), which confimred the findings of previous reports $6,31,32$. However, adding nanosweepers reduced the toxicity of $A \beta_{42} . \mathrm{M}_{2-4}$ containing both $\mathrm{K}$ and $\mathrm{B}$ treated groups showed remarkably higher cell viabilities $\left({ }^{\star} p<\right.$ $0.05,{ }^{* *} p<0.01,{ }^{* *} p<0.001$, Student's t-test) than $\mathrm{M}_{1}$ and $\mathrm{M}_{5}$ treated groups, which only contains either $\mathrm{K}$ or $\mathrm{B}$. This difference in cell viabilities indicated that the combination of both functional peptides resulted in a synergistic anti-A $\beta$-toxicity effect. $\mathrm{M}_{3}$ showed the highest cell viability $(92.5 \%)$, close to that of the control group (100\%) and was screened as the potential lead nanosweeper for clearance of $\mathrm{A} \beta$ and $\mathrm{AD}$ treatment.

To further verify the synergistic anti-A $\beta$ toxicity effect of $M_{3}$, two control peptide-polymers were prepared, $M_{K}$, in which the Beclin-1 peptide was replaced by a control peptide without autophagy activation functionality, and $\mathrm{M}_{\mathrm{B}}$, in which the KLVFF peptide was replaced by a KAAGG peptide without $A \beta$ capture functionality (Supplementary Fig. 3). The chemical structures of both control peptide-polymers were also confirmed by ${ }^{1} \mathrm{H}$ NMR spectra (Supplementary Fig. 4). The cell viability results of $M_{K}$ (78.0\%) and $\mathrm{M}_{\mathrm{B}}(80.9 \%)$ implied that they had lower anti-A $\beta$ toxicity than $\mathrm{M}_{3}$ (Supplementary Fig. 5), which indicated that the enhanced anti-A $\beta$-toxicity seen with $M_{3}$ originated from the synergistic effect of KLVFF and Beclin-1.

Capture of $\mathbf{A} \boldsymbol{\beta}_{42}$ by the nanosweeper. In order to study the ability of the nanosweeper to regognize and co-assemble with $\mathrm{A} \beta_{42}$, we first employed the Thioflavin $\mathrm{T}$ (ThT) fluorescence assay to detect $A \beta$ fibril formation in the presence of $M_{3}$. The ThT assay, an established method of dye binding, was applied to monitor $\mathrm{A} \beta_{42}$ aggregation because its fluorescent spectrum can be altered with the growth of fibrils ${ }^{6}$. Figure 3 a displays a series of sigmoidal curves which are typical of $A \beta_{42}$ fibrillation. The fluorescence intensity of neat $A \beta_{42}$ was higher due to the larger amount of $A \beta_{42}$ fibrillation formation than that of $A \beta_{42}$ in the presence of $M_{3}$, which was similar to the result observed with $M_{K}$, and much lower than that observed with $M_{B}$. The decreasing ThT fluorescence seen from $M_{5}$ to $M_{1}$, together with the increasing KLVFF content (Supplementary Fig. 6), validated the recognition and co-assembly functionality of KLVFF, resulting in the inhibition of $A \beta_{42}$ aggregation. Furthermore, the results of circular 
a

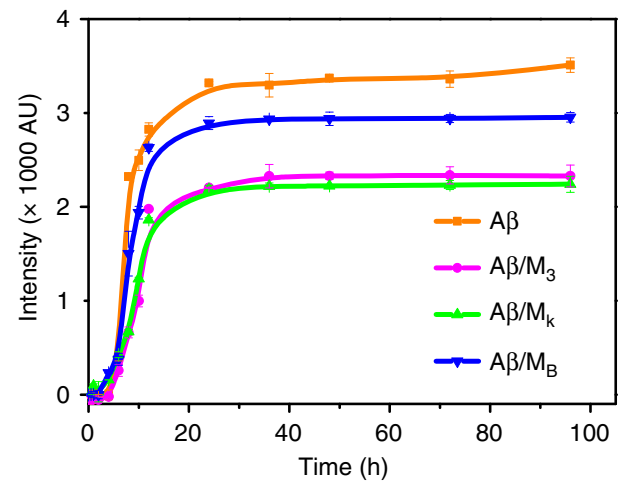

C

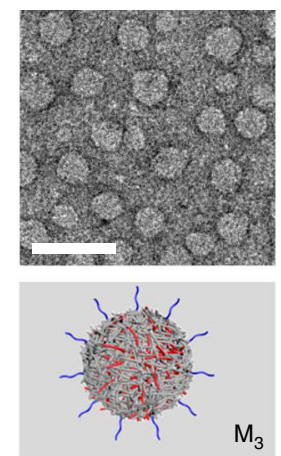

h

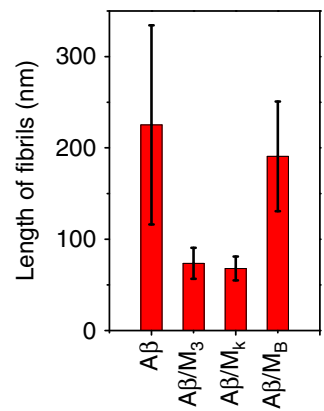

d
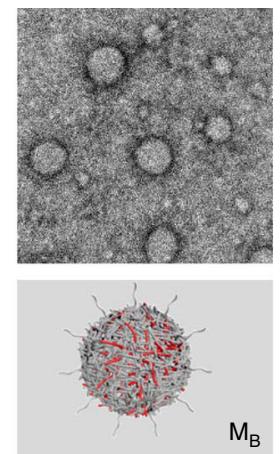

i

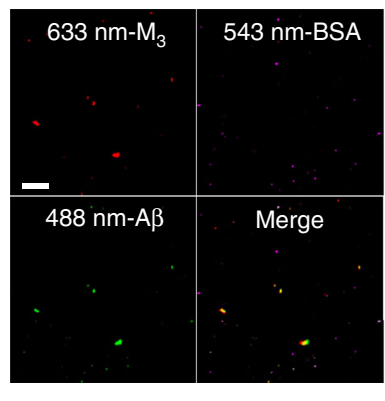

b

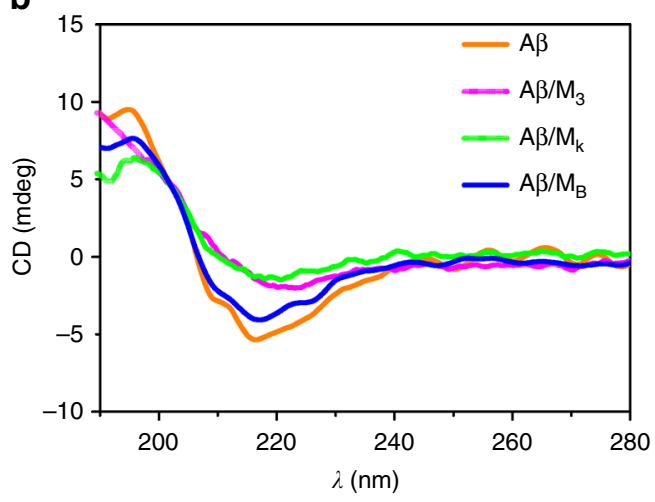

g

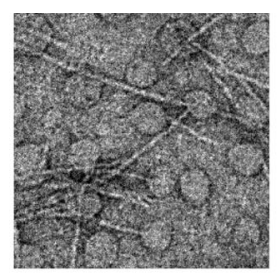

f
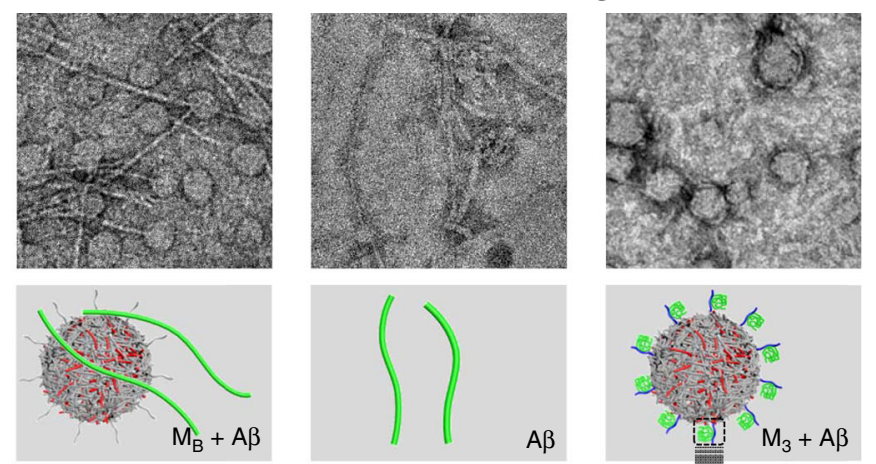

$A \beta$

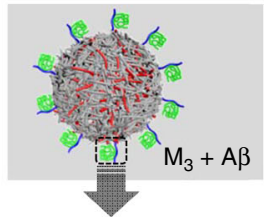

j
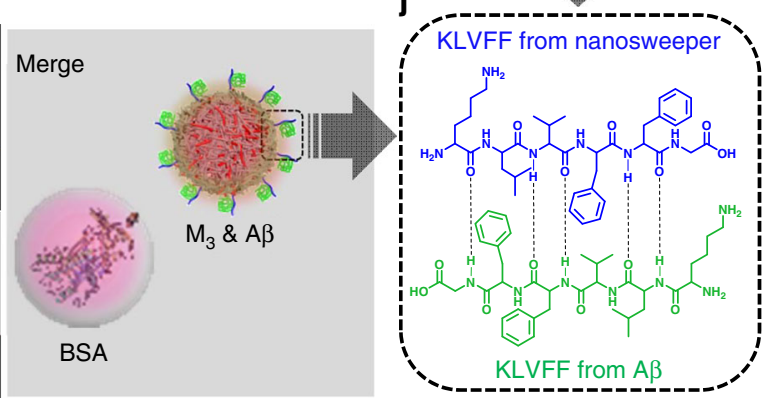

Fig. 3 The capture of $A \beta$ by $M_{3}$ through co-assembly. a ThT fluorescence assay of $A \beta$ and $A \beta / M_{3}$ in 96 h, with $A \beta / M_{K}$ and $A \beta / M_{B}$ as controls. Data are presented as mean \pm s.d. $(n=3)$. $\mathbf{b}$ The $C D$ spectra of $A \beta$ and $A \beta / M_{3}$ at 24 h, with $A \beta / M_{K}$ and $A \beta / M_{B}$ as controls. $\mathbf{c}-\mathbf{g} T E M$ images of $M_{3}, M_{B}, A \beta / M_{B}, A \beta$ and $A \beta / M_{3}$ at $24 \mathrm{~h}$. $\mathbf{h}$ The statistical length of $A \beta$ fibers was averaged from 5 individual fibers per group. Data are presented as mean \pm s.d. $(n=5)$. $\mathbf{i} C L S M$ images and schematic illustration of the mixture of Cy5-labeled $M_{3}$, FITC-labeled A $\beta$ and Cy3.5-labeled BSA. $\mathbf{j}$ The schematic illustration of the driving force for the capture of $A \beta$ by hydrogen bonds. Scale bar: white bar in (c) is $100 \mathrm{~nm}$, and (i) is $20 \mu \mathrm{m}$

dichromism (CD) spectra confirmed that $\mathrm{M}_{3}$ inhibited the formation of $\beta$-sheet structrured $A \beta_{42}$ fibrils (Fig. $3 b$ ). The $A \beta_{42}$ showed random structures at $0 \mathrm{~h}$ (Supplementary Fig. 7) and typical $\beta$-sheet structure at $24 \mathrm{~h}$, with positive and negative signals at 195 and $216 \mathrm{~nm}$, respectively. The $\mathrm{M}_{3}$ or $M_{K}$ treated $A \beta$ did not show typical $\beta$-sheet structures at $24 \mathrm{~h}$, however, the $\mathrm{M}_{\mathrm{B}}$ treated $\mathrm{A} \beta_{42}$ did show typical $\beta$-sheet structures at $24 \mathrm{~h}$. The $\mathrm{CD}$ measurements also revealed the inhibitory effect of $A \beta_{42}$ fibrillation due to KLVFF recognition and co-assembly.

To provide evidence for supporting the binding effect of $\mathrm{M}_{3}$ to $\mathrm{A} \beta_{42}$, transmission electron microscopy (TEM) and dynamic light scattering (DLS) were exploited to detect the evolution of morphology and size distribution in an $A \beta_{42}$ solution in the presence of $M_{3}$, with $M_{B}$ and $M_{K}$ acting as control groups. The $\mathrm{M}_{3}, \mathrm{M}_{\mathrm{B}}$, and $\mathrm{M}_{\mathrm{K}}$ in solution $\left(\mathrm{H}_{2} \mathrm{O}: \mathrm{DMSO}=98: 2,20 \mu \mathrm{g} \cdot \mathrm{mL}^{-1}\right)$ showed similar particulate structures with $43.8 \pm 11.1 \mathrm{~nm}$ diameter at $24 \mathrm{~h}$ (Fig. 3c, d and Supplementary Fig. 8a), and their surfaces could be composed by relative hydrophilic $\mathrm{PEG}_{368^{-}}$ GKLVFF (or $\mathrm{PEG}_{368}$-GKAAGG). Following a $24 \mathrm{~h}$ incubation with $A \beta_{42}$ at $37^{\circ} \mathrm{C}$, TEM images showed that $A \beta_{42}$ incubated with $M_{B}$ clearly contained separate morphologies of nanoparticles and nanofibers (Fig. $3 \mathrm{e}$ ) at $24 \mathrm{~h}$, which were potentially originated from $M_{B}$ and $A \beta_{42}$ (Fig. 3f), respectively. However, the $A \beta_{42}$ incubated with $\mathrm{M}_{3}$ and $\mathrm{M}_{\mathrm{K}}$ contained main species of particulate structures entangled with some fibers (Fig. $3 \mathrm{~g}$ and Supplementary Fig. 8b), the morphology of which was totally different from free mature $\mathrm{A} \beta_{42}$ fibrils. Interestingly, the statistics obtained from the fiber length taken from the TEM images of $A \beta_{42}$, and $\mathrm{A} \beta_{42} / \mathrm{M}_{\mathrm{B}}$ showed similar lengths, $225 \pm 109$ and $191 \pm 60 \mathrm{~nm}$ (Fig. 3h), respectively. The statistical length of $A \beta_{42} / M_{3}$ and $A \beta_{42} /$ $M_{K}$ was decreased to $74 \pm 17$ and $68 \pm 13 \mathrm{~nm}$, respectively, suggesting that $M_{3}$ and $M_{K}$ could co-assemble with $A \beta_{42}$ and inhibit the formation of free mature $A \beta_{42}$ fibrils, probably through KLVFF recognition and binding unit. These TEM results 


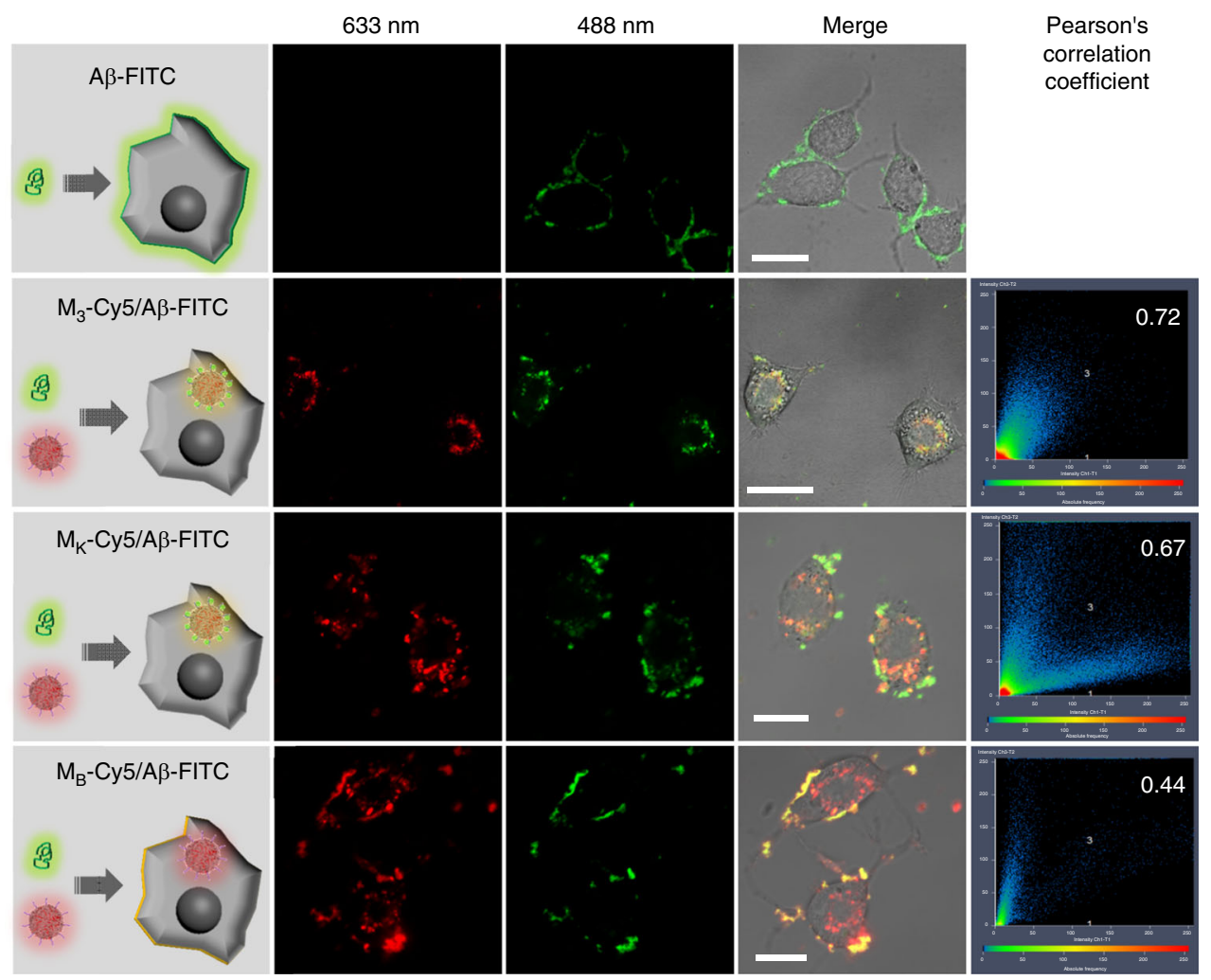

Fig. $4 \mathrm{~A} \beta$ was internalized into cells with $M_{3}$ nanosweeper. Schematic (row 1) and CLSM measurements of N2a cells treated with $A \beta$, a mixture of $A \beta / M M_{3}$, $A \beta / M_{K}$ and $A \beta / M_{B}$ (row 2, 633 nm; row 3, 488 nm; row 4, Merge). Scale bar: $20 \mu \mathrm{m}$

were in accordance with the DLS measurement (Supplementary Fig. 9).

Confocal laser scanning microscopy (CLSM) was further employed to validate the specific co-assembly of $A \beta_{42}$ and $M_{3}$. We first labeled $\mathrm{M}_{3}$ nanosweeper and $\mathrm{A} \beta_{42}$ with $\mathrm{Cy} 5\left(\mathrm{M}_{3}\right.$-Cy5) (Supplementary Fig. 10) and FITC $\left(\mathrm{A} \beta_{42}\right.$-FITC), respectively. The $\mathrm{M}_{3}$-Cy5 and $\mathrm{A} \beta_{42}$-FITC were mixed in water and co-localized well by CLSM measurement, so was $\mathrm{M}_{\mathrm{K}}$-Cy5 with $\mathrm{A} \beta_{42}$-FITC (Supplementary Fig. 11). However, there were no obvious colocalization observed between $\mathrm{M}_{\mathrm{B}}-\mathrm{Cy} 5$ and $\mathrm{A} \beta_{42}$-FITC, indicating that the KLVFF induced the co-assembly of $M_{3} / M_{K}$ and $A \beta_{42}$. In order to confirm the specificity, Cy3.5-labeled bovine serum albumin (BSA), a kind of serum albumin, accoutning for $55 \%$ of blood proteins, was utilized as a competing regent. The $\mathrm{M}_{3}-\mathrm{Cy} 5$, $\mathrm{A} \beta_{42}$-FITC, and BSA-Cy3.5 were mixed together, and observed by CLSM. The results clearly displayed that the $\mathrm{M}_{3}$-Cy5 co-localized with $\mathrm{A} \beta_{42}$-FITC, but not BSA-Cy3.5, providing strong evidence for the specific co-assembly between $\mathrm{M}_{3}$-Cy5 and $\mathrm{A} \beta_{42}$-FITC (Fig. 3i,j).

Delivery of $A \beta_{42}$ into cells by the nanosweeper. To confirm that the $A \beta_{42}$ was substantially internalized into neutron cells by $M_{3}$, N2a cells in a confocal petri dish $(20 \mathrm{~mm})$ were treated with $A \beta_{42^{-}}$ FITC $(20 \mu \mathrm{M}), \mathrm{M}_{3}-\mathrm{Cy} 5, \mathrm{M}_{\mathrm{K}}-\mathrm{Cy} 5, \mathrm{M}_{\mathrm{B}}$-Cy5 $\left(20 \mu \mathrm{g} \cdot \mathrm{mL}^{-1}\right)$ and a mixture of $\mathrm{A} \beta_{42}-\mathrm{FITC} / \mathrm{M}_{3}-\mathrm{Cy} 5, \mathrm{~A} \beta_{42}-\mathrm{FITC} / \mathrm{M}_{\mathrm{K}}-\mathrm{Cy} 5, \mathrm{~A} \beta_{42}$-FITC/ $\mathrm{M}_{\mathrm{B}}-\mathrm{Cy} 5$ and observed by CLSM (Fig. 4). As can be seen in Fig. 4, the $\mathrm{A} \beta_{42}$-FITC treated N2a cells exhibited green signal on cell surfaces, but not in the cytoplasmic matrix. This finding indicated that $\mathrm{A} \beta_{42}$ might get stuck in the membrane during internalization into cells, due to its hydrophobicity, which most likely led to neurotoxicity in the N2a cells. Nanosweepers, such as $\mathrm{M}_{3}-\mathrm{Cy} 5$, $\mathrm{M}_{\mathrm{K}}-\mathrm{Cy} 5$, and $\mathrm{M}_{\mathrm{B}}-\mathrm{Cy} 5$ were internalized into cells with red fluorescence in cytoplasm (Supplementary Fig. 12). As expected, N2a cells treated with $A \beta_{42}$-FITC/M $3_{3}$-Cy5 showed green $A \beta_{42^{-}}$
FITC fluorescence co-localized with $\mathrm{M}_{3}-\mathrm{Cy} 5$ (Pearson's correlation coefficient $(\mathrm{PCC})=0.72)$ inside cells, due to the capture of $A \beta_{42}$ by the $M_{3}$ nanosweeper and the subsequent high-efficiency internalization into cells (Fig. 4). $\mathrm{M}_{3}$ increased the internalization of $A \beta_{42}$ through co-assembly, not attaching on cell surfaces. The positive control group cells that were treated with $A \beta-F I T C / \mathrm{M}_{\mathrm{K}^{-}}$ Cy5 displayed the colocalized fluorescence of $A \beta_{42}$-FITC and $M_{K}-$ Cy5 inside cells with PCC of 0.67 , similar to the $A \beta_{42}-\mathrm{FITC} / \mathrm{M}_{3}$ Cy5 group. However, the group treated with $\mathrm{A} \beta_{42}-\mathrm{FITC} \mathrm{M}_{\mathrm{B}}-\mathrm{Cy} 5$ $(P C C=0.44)$ showed red fluorescence $\left(\mathrm{M}_{\mathrm{B}}-\mathrm{Cy} 5\right)$ inside cells and merged $A \beta_{42}$-FITC and $\mathrm{M}_{\mathrm{B}}-\mathrm{Cy} 5$ on cell surfaces (Supplementary Fig. 13). These results suggested that $M_{B}$ entered the cells alone, and that the $A \beta_{42}$-FITC stuck on cell surfaces as usual. When cell surfaces were covered with $A \beta_{42}$-FITC, the $M_{B}-C y 5$ may no longer be able to enter cells, but stayed on cell surfaces, showing the merged fluorescence signals on cell surfaces. Therefore, the co-assembly of $M_{3}$ and $A \beta_{42}$ not only inhibited the $A \beta_{42}$ fibril formation, but also increased the internalization of $A \beta_{42}$.

Inducement of autophagy by the nanosweeper in vitro. In order to validate the autophagy effect of $\mathrm{M}_{3}$ on N2a cells, autophagic structures and the marker protein LC3-II were measured using Acridine Orange staining, Bio-TEM, and western blot methods. Acridine Orange $(\mathrm{AO})$ is a $\mathrm{pH}$-sensitive dye and typically used as non-specific chemical agent for autophagy detection. It can mark acidic vesicular organelles with red and cytoplasm and DNA with green $^{30}$. The ratio of red/green has been used widely to evaluate levels of autophagy ${ }^{33,34}$. The N2a cells were incubated with $M_{3}$, and $M_{B}$ and $M_{K}$ as controls for $4 \mathrm{~h}$, then stained with $A O$ dyes for $10 \mathrm{~min}$, followed by observation by CLSM. As shown in Supplementary Fig. 14a, there were many red spots in the $\mathrm{M}_{3}$-treated and $\mathrm{M}_{\mathrm{B}}$-treated cells. In contrast, $\mathrm{PBS}$ and $\mathrm{M}_{\mathrm{K}}$ treated cells showed few red spots. The quantification of fluorescence revealed that the red/green signal ratios of the $\mathrm{M}_{3}$-treated and $\mathrm{M}_{\mathrm{B}}$-treated 
a
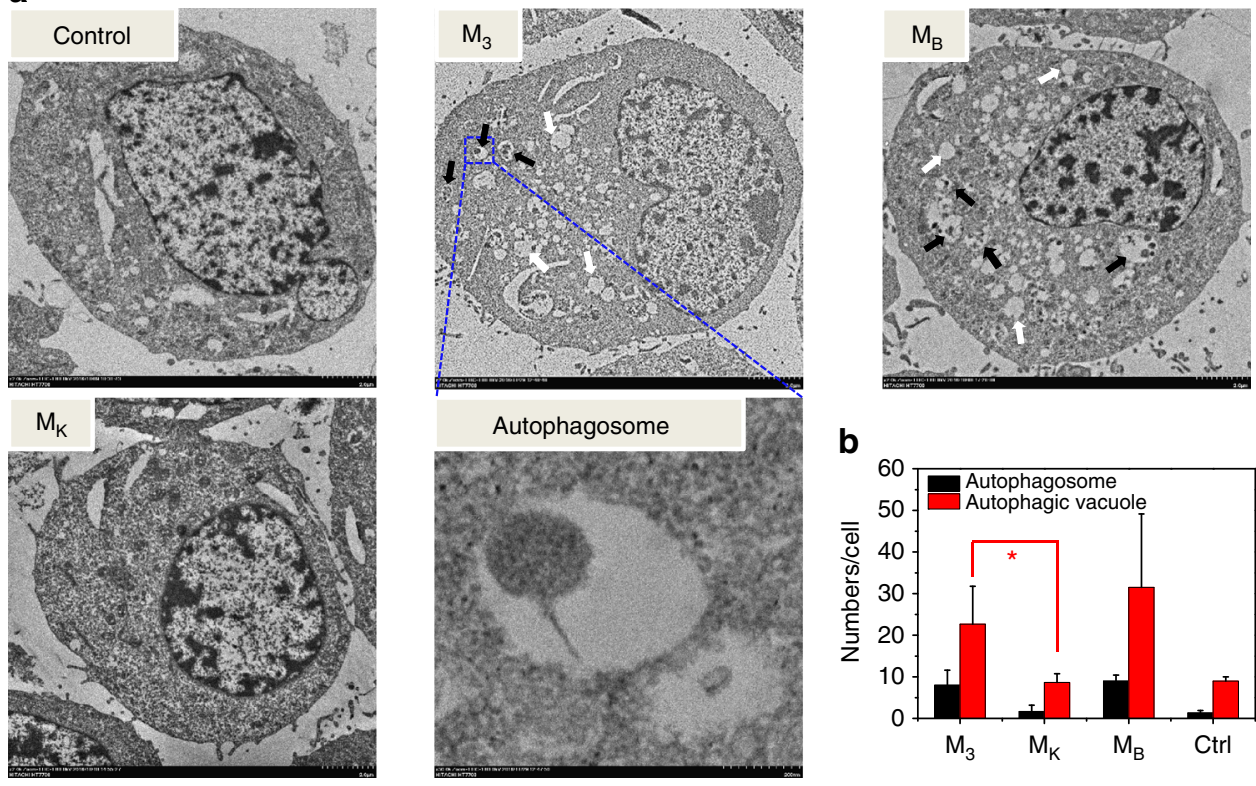

C

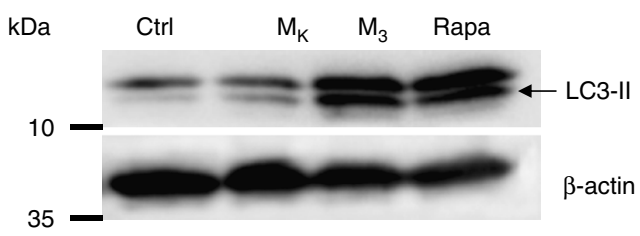

d

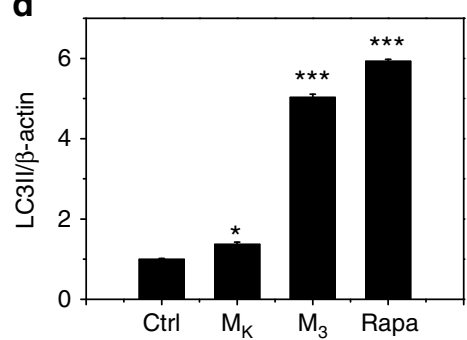

Fig. $5 \mathrm{M}_{3}$ activated autophagy significantly in vitro. a TEM images of N2a cells. The N2a cells were treated with PBS (control), MK (200 $\left.\mu g / m L\right)$ and $M_{3}$ $(200 \mu \mathrm{g} / \mathrm{mL})$, and $M_{B}(200 \mu \mathrm{g} / \mathrm{mL})$. The autophagic structures are indicated by black arrows (autophagosome), and white arrows (autophagic vacuoles). b The static results of autophagic structures were obtained from three random TEM images. Data are presented as mean $\pm \mathrm{s}$.d. $(n=3)$. c Western blot of LC3-II and (d) the corresponding quantified results. N2a cells were treated for $24 \mathrm{~h}$ with PBS (control), $\mathrm{M}_{\mathrm{K}}(200 \mu \mathrm{g} / \mathrm{mL}), \mathrm{M} 3(200 \mu \mathrm{g} / \mathrm{mL})$, and Rapa $(1 \mu \mathrm{M})$. Data are presented as mean \pm s.d. $(n=3)$. Statistical significance is indicated as ${ }^{\star} p<0.05,{ }^{\star \star} p<0.01$, and ${ }^{\star \star *} p<0.001$, for comparison with control group (Student's $t$-test)

groups were remarkably higher than those of the PBS-treated and $\mathrm{M}_{\mathrm{K}}$-treated cells (Supplementary Fig. $14 \mathrm{~b},{ }^{* * *} p<0.001$ ).

In addition, bio-TEM, a standard method for autophagy detection, was applied to examine the autophagic structures (autophagosome and autolysosome) of $\mathrm{N} 2$ a cells. The N2a cells were first treated with $M_{3}, M_{K}$ and $M_{B}$ for $4 \mathrm{~h}$, after which the cells were harvested and prepared for bio-TEM imaging using our previous method ${ }^{35}$. Finally, a JEOL JEM-1400 electron microscope was used to observe cells. As shown in Fig. 5a, an increase in the amount of small double/multi-membrane vesicles (autophagosome, black arrow) and huge vacuoles (autolysosome, white arrow) were observed in the $\mathrm{M}_{3}$-treated and $\mathrm{M}_{\mathrm{B}}$-treated cells, compared with the PBS group. However, there were minimal autophagic structures in the $\mathrm{M}_{\mathrm{K}}$-treated cells. The statistic results showed dramatic differences between $M_{K}$ and $M_{3}$ treated groups (Fig. $5 \mathrm{~b},{ }^{*} p<0.05$ Student's $t$-test). In addition, the results of western blotting for LC3-II, an autophagy marker protein, confirmed that $\mathrm{M}_{3}$ increased the expression of LC3-II significantly (Fig. 5c, d). The above results lent strong support to the hypothesis that Beclin-1 residues in $\mathrm{M}_{3}$ could effectively induce autophagy in vitro.

Autophagic degradation induced by the nanosweeper in vitro. We studied the autophagic flux of N2a cells in order to explore whether or not intracellular $M_{3} \& A \beta_{42}$ adduct could be degraded by the autophagic process. $\mathrm{M}_{3}$ was first labeled with $\mathrm{Cy} 5$ (red signal). Next, the GFP-LC3 transfected N2a cells were incubated with $\mathrm{M}_{3}-\mathrm{Cy} 5 \& \mathrm{~A} \beta_{42}\left(20 \mu \mathrm{g} \cdot \mathrm{mL}^{-1} / 20 \mu \mathrm{M}\right)$ for $4 \mathrm{~h}$, followed by CLSM observation. Generally, LC3-II was recruited to the autophagosome membrane and thereby formed a green dot of GFP-LC3 when autophagy was activated ${ }^{36,37}$. As expected, the CLSM images revealed that most of the $\mathrm{M}_{3}-\mathrm{Cy} 5$ (red signal) colocalized with autophagosomes (GFP-LC3, green signal) (Fig. 6a), indicating that $\mathrm{M}_{3} \& A \beta_{42}$ was delivered to autophagosomes. Generally, the autophagosome would be fused with the lysosome, forming an autolysosome for degredation of cargo ${ }^{38}$. So, we therefore measured the colocalization of $\mathrm{M}_{3}$-Cy5\&A $\beta_{42}$ with autolysosomes. p62, An autolysosome marker protein that is preferentially degraded by autophagic process, was marked with green fluorescence through an immunofluorescence technique. The results displayed that the green immunofluorescence signals from $\mathrm{p} 62$ and red fluorescence signals from $\mathrm{M}_{3}$-Cy5 were highly merged (Fig. 6b), indicating that $M_{3} \& A \beta_{42}$ was transferred into the autolysosome for degradation (Fig. 6c). To further confirm autophagic degradation, we used western blotting to detect the autophagic flux based on expression of p62. As shown in Fig. 6d, $\mathrm{M}_{3}$ upregulated the expression of p62, similarly to HCQ and Rapa. However, $\mathrm{M}_{3}$ did not induce obvious p62 upregulation of the Rapa-treated group, but increased accumulation of p62 in the HCQ-treated group, with a p62/ $\beta$-actin ratio from 2.58 to 3.10 
a
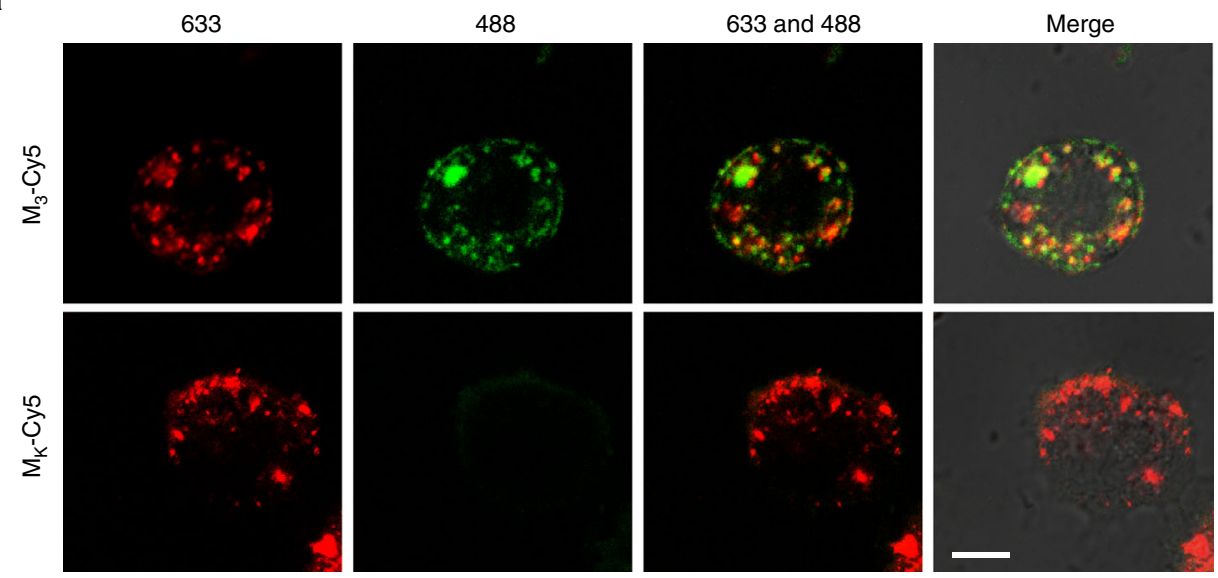

b
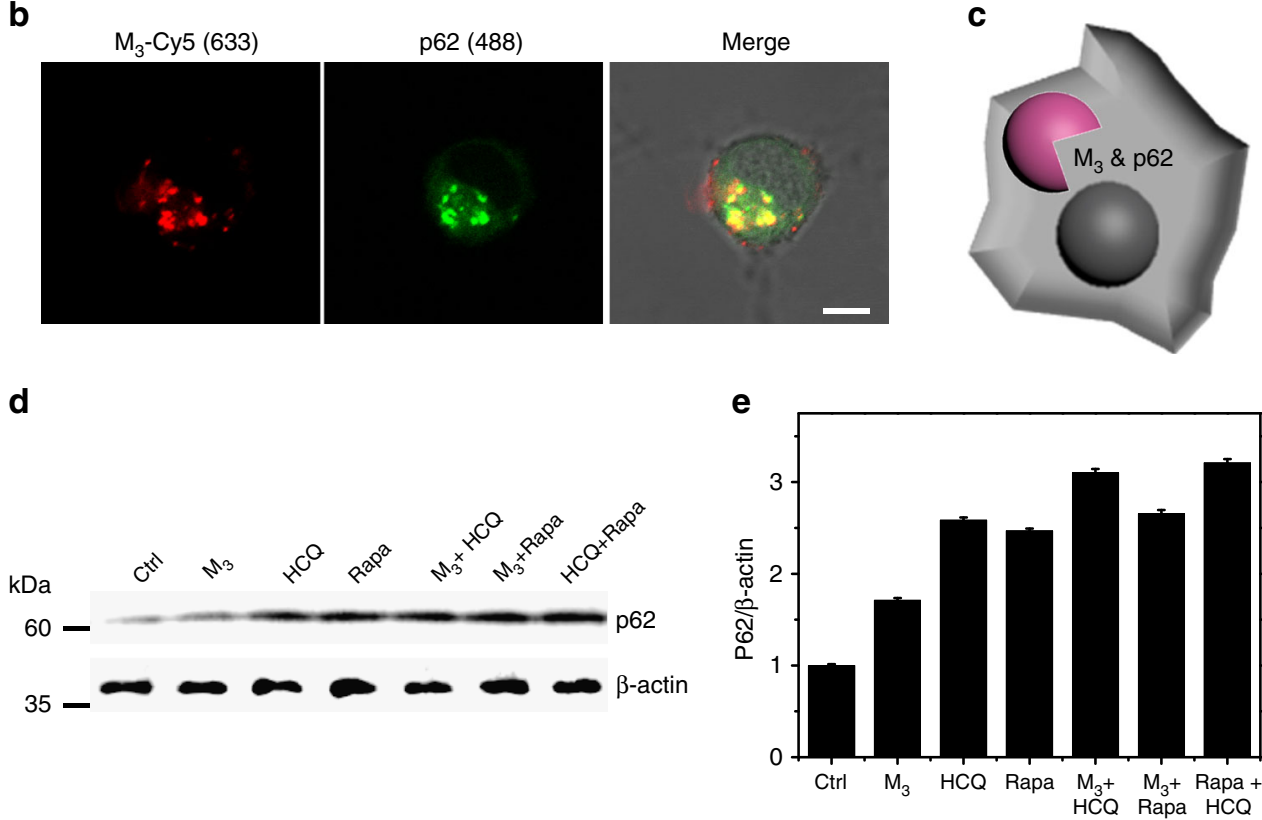

Fig. $6 \mathrm{M}_{3}$ induced autophagic degradation in vitro. a CLSM images showed the co-localization of the autophagosome (GFP-LC3-positive puncta, green signals) and $M_{3}-C y 5$ (red signals). N2a/GFP-LC3 cells were treated with $M_{3}-C y 5(200 \mu g / m L)$ and $M_{K}-C y 5$ as a control for 24 h. b CLSM images showed the co-localization of $\mathrm{M}_{3}-\mathrm{Cy} 5$ (red signals) and p62 (green signals from anti-p62-labeled secondary antibody). c The schematic illustration of $\mathrm{M}_{3}$ degradation by autophagy. $\mathbf{d}$ Western blot of $\mathrm{p} 62$ and (e) the corresponding quantified results. N2a cells were cultured as follows: in regular culture medium for $24 \mathrm{~h}$ (lane 1); $\mathrm{M}_{3}\left(200 \mu \mathrm{g} / \mathrm{mL}\right.$ ) for $24 \mathrm{~h}$ (lane 2); $5 \mu \mathrm{M} \mathrm{HCQ}$ for $1 \mathrm{~h}$ (lane 3); $1 \mu \mathrm{M}$ Rapa for $1 \mathrm{~h}$ (lane 4 ); with $\mathrm{M}_{3}$ (200 $\mu \mathrm{g} / \mathrm{mL}$ ) and HCQ (lane 5); with $M_{3}(200 \mu \mathrm{g} / \mathrm{mL})$ and Rapa (lane 6); with Rapa and HCQ (lane 7). Data are presented as mean \pm s.d. $(n=3)$. Scale bar in $(\mathbf{a}, \mathbf{b})$ is $10 \mu \mathrm{m}$

(Fig. 6e). These findings validated that $\mathrm{M}_{3}$ activated autophagy without blockade of the autophagic flux, indicating the possibility of autophagic degradation of $\mathrm{A} \beta_{42}$.

Crossing BBB and activating autophagy in vivo. For the in vivo experiment, the nanosweeper should be effectively delivered into brain. Cyclosporine was verified to effectively increase the permeability of blood-brain barrier (BBB) through influencing P-gp function in the $\mathrm{BBB}^{39,40}$. In order to evaluate how $\mathrm{M}_{3}$ nanosweeper crossed the $\mathrm{BBB}$, we intravenously injected cyclosporine $(10 \mu \mathrm{M})$ into mice, followed by i.v. administration of a dose of $200 \mu \mathrm{g} \cdot \mathrm{mL}^{-1} \mathrm{M}_{3}$ nanosweeper, which was labeled by Cy5. The mice were sacrificed and the brains were harvested for ex vivo imaging. As shown in Supplementary Fig. 15, the higher fluorenscence signal in cyclosporine and $\mathrm{M}_{3}$-Cy5 nanosweepers indicated that cyclosporine made more $\mathrm{M}_{3}$ nanosweepers reaching to the brain, compared with $\mathrm{PBS}$ or $\mathrm{M}_{3}-\mathrm{Cy} 5$ nanosweeper treated group. Furthermore, for quantifying the efficiency of $\mathrm{M}_{3}$ nanosweepers crossing BBB, we loaded the very small gold NPs into $\mathrm{M}_{3}$ nanosweepers, and i.v. injected into the mice $30 \mathrm{~min}$ after cyclosporine i.v. administration. The $\mathrm{M}_{3}$ nanosweepers distribution in the brain was characterized by gold amount, which was measured by inductively coupled plasma mass spectrometry. $\mathrm{M}_{3}$ nanosweepers reaching the brain could be calculated as $1.94 \%$ of total injection (Fig. 7a).

The activation of autophay in the brain determined the therapeutic effect, the immunohistochemical method was utilized for confirming the autophagic process of hippocampal neuron activated by $\mathrm{M}_{3}$ nanosweepers. Sections of the hippocampi from mice were stained with LC3 antibody marked with FITC. The CLSM images displayed an increased dots of green signals (autophagic structures) in the $\mathrm{M}_{3}$-treated mice than that of the wild type (WT) and AD groups (Fig. 7b), indicating the more LC3, the biomarker of autophagy in $\mathrm{M}_{3}$ treated mice brain. In addition, brain slices of $A D$ mice treated with $M_{3}$ were observed by bio-TEM, and the results were shown in Fig. 7c. There were a 


\begin{tabular}{|c|c|c|c|c|c|c|}
\hline $\mathrm{M}_{3}$-Au $(\mu \mathrm{g} / \mathrm{L})$ & No.1 & No. 2 & No. 3 & No. 4 & Ave & Ave\% \\
\hline In the brain & 0.05 & 0.01 & 0.02 & 0.04 & 0.03 & 1.94 \\
\hline Total & 1.32 & 1.82 & 1.53 & 1.53 & 1.55 & 100 \\
\hline
\end{tabular}

b
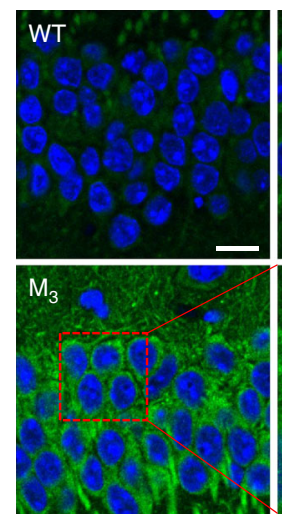
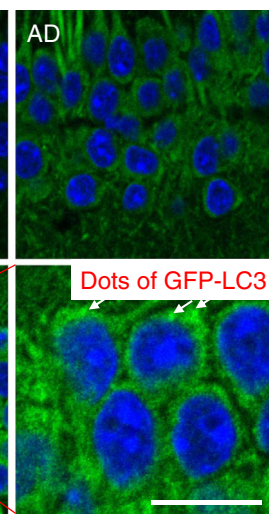

C

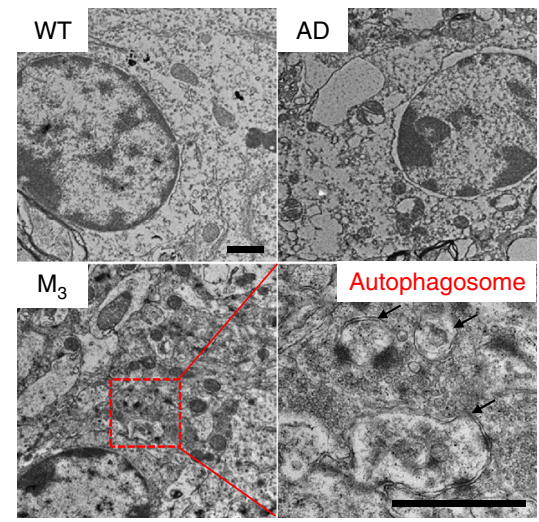

Fig. 7 In vivo evaluation of $M_{3}$ crossing BBB and activating autophagy. a The concentration of Au in the brain and in the total injection solution, respectively. The amount of $M_{3}$ actually reached to the brain was evaluated by Au amount: $M_{3} \%=0.03 / 1.55 \times 100 \%=1.94 \%$. $(n=4)$. b CLSM images and $\mathbf{c}$ bio-TEM images of brain tissue slices of AD mice treated by PBS or $M_{3}$, and WT mice treated with PBS as a control. The dots of GFP-LC3 (white arrow in $\mathbf{b}$ ) and the strucuture of autophagsome (black arrow in c) were pointed out in $M_{3}$ treated AD mice, respectively. Scale bar in (b) is $20 \mu \mathrm{m}$. Scale bar in (c) is $1 \mu \mathrm{m}$

lot of autophagic structures in $\mathrm{M}_{3}$ treated group, but not observed in $\mathrm{WT}$ and $\mathrm{AD}$ groups without treatment. These results suggested that $M_{3}$ could effectively induce the autophagic process in vivo.

Clearance of $\mathbf{A} \boldsymbol{\beta}$ and rescue of memory deficits. In order to further study whether or not the $\mathrm{M}_{3}$ nanosweeper could reduce amyloid plaques in the brains of $\mathrm{AD}$ mice, $\mathrm{M}_{3}$ nanosweeper was utilized to treat APPswe/PS1dE9 transgenic mice every other day for one month ${ }^{15,16,41}$. Following the treatment period, the amount of soluble $A \beta_{42}$ and insoluble $A \beta_{42}$ in the brain tissue was measured by enzyme-linked immune sorbent assay (ELISA) (Fig. 8a,b), and confirmed that soluble $A \beta_{42}$ and insoluble $A \beta_{42}$ were decreased by $\mathrm{M}_{3}$ treatment, which was obvious lower than those of $\mathrm{AD}$ mice without treatment. As expected, $\mathrm{M}_{3}$ nanosweeper may capture $A \beta_{42}$ to form $M_{3}$ and $A \beta_{42}$ and enter into cells, followed by activation of autophagy and degradation of $A \beta_{42}$ intracellluarly, leading to the decrease of soluble $A \beta_{42}$. The decrease of soluble $A \beta_{42}$ further resulted in the decrease of $A \beta_{42}$ aggregation, i.e., insoluble $A \beta_{42}$. Furthermore, immunohistochemistry analysis was carried out to label $A \beta$ deposition in the brains. As shown in Fig. 8c, a large amount of $A \beta$ deposition (circled with red dotted line) was observed in the $\mathrm{AD}$ control mice, and the difference was obvious between those and the WT control mice. Importantly, in the brains of $\mathrm{AD}$ mice treated with $\mathrm{M}_{3}$ nanosweeper, there was a significant decrease in the $\mathrm{A} \beta$ plaque load, indicating that $M_{3}$ nanosweeper had the ability to reduce $A \beta$ deposition, which was in agreement with the measurments of $A \beta$ in the brain. The soluble and insoluble $A \beta$ in the brain of $\mathrm{AD}$ mice treated with $\mathrm{M}_{3}$ was also decreased (Supplementary Fig. 16), but not as much as the extend of decrease in $A \beta_{42}$, probably indicating the specificity of $M_{3}$ for capture of $A \beta_{42}$ by KLVFF. The results of Nissl staining of nerve cells revealed an obvious neuronal hypocellularity in the brain of $\mathrm{AD}$ control mice, which had small amounts of Nissl bodies (blue) (Fig. 8d). Contrastingly, $\mathrm{M}_{3}$ nanosweeper treatment significantly attenuated neuron loss in $\mathrm{AD}$ mice. Together, these results indicated that $\mathrm{M}_{3}$ nanosweeper could effectively decrease soluble $A \beta_{42}$ and insoluble $\mathrm{A} \beta_{42}$, as well as the the deposition of $\mathrm{A} \beta$ and toxicity in nerve cells.
The Morris water maze (MWM) test was utilized to investigate the effect of $\mathrm{M}_{3}$ nanosweeper on the spatial cognitive performance of APPswe/PS1dE9 transgenic mice. The escape latencies of $\mathrm{M}_{3}$-treated mice for searching for the hidden platform were measured daily for 4 days. As shown in Fig. 8e, both WT mice and $\mathrm{M}_{3}$ nanosweeper-treated $\mathrm{AD}$ mice exhibited significantly shorter latency than the $\mathrm{AD}$ control group on days 2, 3, and 4, indicating that $\mathrm{M}_{3}$ nanosweeper could markedly improve the spatial memory of AD mice. When the training was completed, the place of the platform was removed and the mice were given $60 \mathrm{~s}$ to find the missing platform for the probe trial. As shown in Fig. 8f, the $M_{3}$ nanosweeper-treated AD mice exhibited spatially oriented swimming behavior and shorter latencies than $\mathrm{AD}$ control mice. These outcomes were further confirmed by the percentage of time spent in the target quadrant (Fig. 8g). The number of times $\mathrm{M}_{3}$ nanosweeper-treated mice entered the small target zone was 2.4, which was greater than that of the $\mathrm{AD}$ mice (1.6 times). In order to evaluate long-term therapetuic effect, $\mathrm{M}_{3}$ nanosweeper was utilized to treat APPswe/PS1dE9 transgenic mice every other day for one month, and the MWM was tested two month post-treatment. The searching ability for the hidden platform of $\mathrm{AD}$ mice treated with $\mathrm{M}_{3}$ nanosweeper was obviously enhanced (Supplementary Fig. 17), similar as the above results, revealing that the excellent long-term therpeutic effects of $M_{3}$ nanosweeper. The systemic toxicity of $\mathrm{M}_{3}$ was further investigated by hematology and histopathology assays (Supplementary Figs. 18 and 19). No significant differences were detected in pathological signs (heart, liver, spleen, lung, and kidney) between the $\mathrm{M}_{3}$-treated group and the control groups (WT and AD). All of above results suggested that $\mathrm{M}_{3}$ did not cause any obvious side effects and could be used safely as a biomaterial with excellent rescue of memory deficits in $\mathrm{AD}$ transgenic mice.

\section{Discussion}

In summary, we successfully developed a multifunctional peptidepolymer based nanosweeper $\left(\mathrm{M}_{3}\right)$, which could specifically capture $A \beta$ via recognition and co-assembly with $A \beta$, followed by delivery of $A \beta$ into cells. The nanosweeper promoted degradation of $A \beta$ through the upregulation of autophagy. Both in vitro and 
a

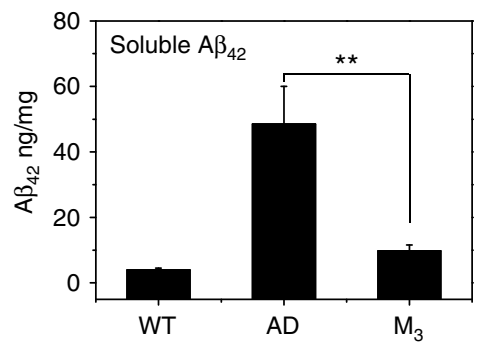

C

d

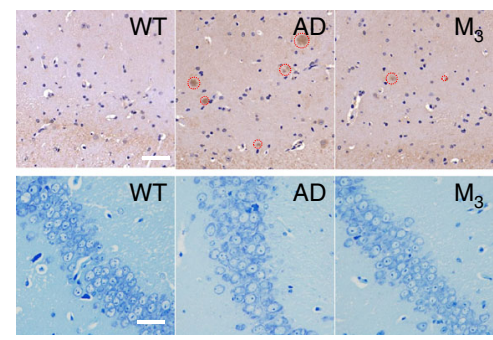

f

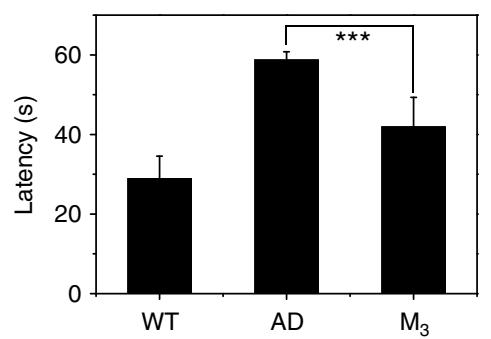

h

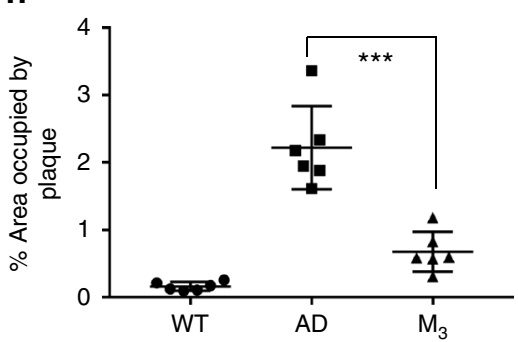

b

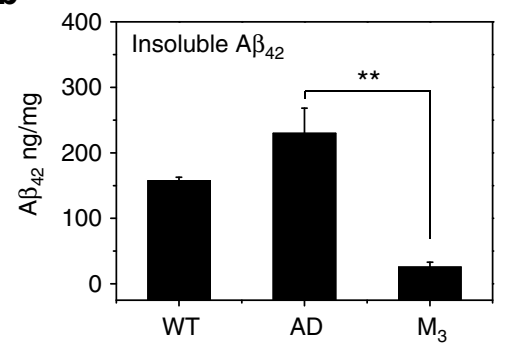

e

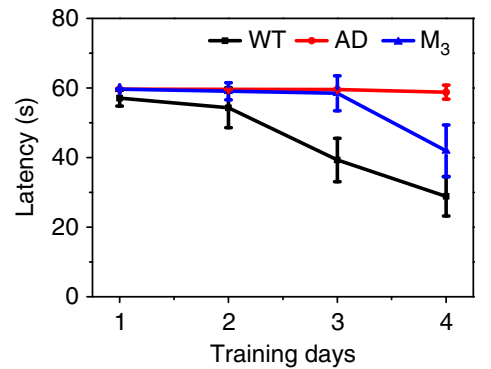

g

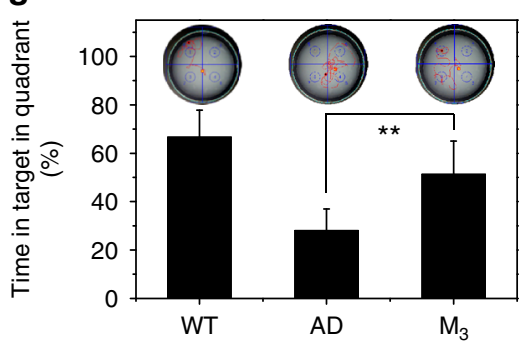

i

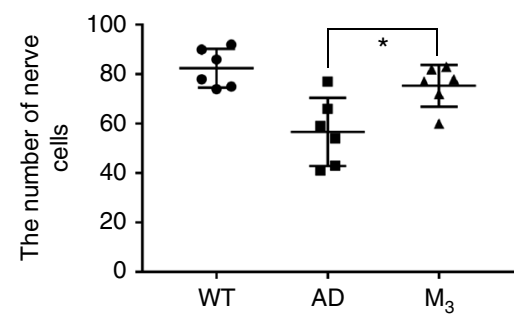

Fig. 8 In vivo evaluation of $M_{3}$ for the clearance of $A \beta$ and decreasing cytotoxicity. a Soluble $A \beta_{42}$ and (b) insoluble $A \beta_{42}$ in the brain measured by ELISA. $(n=4)$. c The immunohistochemical analysis of $A \beta_{42}$ deposition in the brains of WT control mice, AD control mice, $A D$ mice treated with $M_{3}$. The $A \beta_{42}$ deposits appeared as brown signals as indicated by red dotted circle. Scale bar is $50 \mu \mathrm{m}$. $\mathbf{d}$ The Nissl staining of nerve cells in the brains of WT control mice, $A D$ control mice, AD mice treated with $M_{3}$. The Nissl bodies were stained blue. Scale bar is $50 \mu \mathrm{m}$. e The latencies of WT control mice, AD control mice, and $A D$ mice treated with $M_{3}$ (three mice per group). $\mathbf{f}$ The latency during the memory test in the MWM probe trial without a platform. $\mathbf{g}$ The percent (\%) of time in the targeted quadrant where the platform had been located during the memory test in the MWM probe trial. $\mathbf{h}$, $\mathbf{i}$ were the quantified results of $(\mathbf{c}, \mathbf{d})$, respectively. Data are presented as mean \pm s.d. $(n=6)$. The data between AD group and $M_{3}$ group are analyzed by a Student's $t$-test. Statistical significance is indicated as ${ }^{\star} p<0.05,{ }^{\star \star} p<0.01$, and ${ }^{\star \star \star} p<0.001$

in vivo experiments were performed to validate this hypothesis and the remarkable resulting anti-AD therapeutic effect. $\mathrm{M}_{3}$ increased the cell viability of $\mathrm{N} 2 \mathrm{a}$ cells, which was induced by $\mathrm{A} \beta$. Moreover, $\mathrm{M}_{3}$ decreased $\mathrm{A} \beta$ deposition in the brains of APPswe/ PS1dE9 transgenic mice and rescued their memory deficits. The nanosweeper could have clinical practicality and provide an efficient therapeutic system for clearance of $A \beta$. Collectively, our findings support the potential for this new multifunctional peptide-polymer, the nanosweeper, as an promising therapeutic agent for the treatment of $\mathrm{AD}$, opening up a new avenue for therapeutic applications.

\section{Methods}

Materials. Chitosan (CS, average Mw 5000), acryloyl chloride (TCI, Shanghai, China), Methoxy poly(ethylene glycol) $\left(\mathrm{CH}_{3} \mathrm{O}-\mathrm{PEG}_{\mathrm{n}}-\mathrm{CH}_{2} \mathrm{CH}_{2} \mathrm{COOH}\right)\left(\mathrm{M}_{\mathrm{n}}=368\right)$ was purchased from Jiaxing Biomatrix and Biotechnology Inc. Thioflavine-T, Cy3.5 and Cy5 were obtained from Sigma-Aldrich. 1,1,1,3,3,3-Hexafluoro-2-propanol (HFIP) and dimethyl sulfoxide (DMSO) were purchased from Aldrich Chemical Co. and used without further purification. A $\beta$, FITC-A $\beta$, Beclin-1 (B) (>95\%) and scrambled Beclin-1 peptide (B') (>95\%) were customized from GL Biochem Ltd. (Shanghai, China). $A \beta_{42}$ was pre-treated with HFIP, followed by evaporation with $\mathrm{N}_{2}$ and stored at $-20{ }^{\circ} \mathrm{C}$. Cell counting kit-8 assay (CCK-8) (Beyotime Institute of Biotechnology, China) were used without further purification. Other solvents and reagents were used as received. 
Preparation of peptides. Firstly, acryl-CS was obtained as our previous reports. Peptide CFFVLKG-PEG (abbreviate to K) and CGGAAKG-PEG (abbreviate to K') were prepared by standard solid phase peptide synthesis techniques using $\mathrm{F}_{\text {moc }}$ coupling chemistry. Acryl-CS (0.021 g, $0.1 \mathrm{mM}$ for acrylamide bonds) was dissolved in PBS solution (2.1 mL, pH 8.0), $0.12 \mathrm{mM}$ peptides in total with different ratio of $\mathrm{m} / \mathrm{n}(1: 0,0.75: 0.25,0.5: 0.5,0.25: 0.75,0: 1)$ were dissolved in $2.1 \mathrm{~mL}$ DMSO, followed by dropwise addition into acryl-CS solution under magnetic stirring. Then, the mixtures were bubbled with $\mathrm{N}_{2}$ for 30 min under stirring and reacted at $37^{\circ} \mathrm{C}$ for $48 \mathrm{~h}$ in the dark. After the reaction, the resultant solution was dialyzed against deionized water (MWCO: $3500 \mathrm{Da}$ ) for $24 \mathrm{~h}$ and lyophilized to obtain a pale yellow solid. $\mathrm{M}_{\mathrm{K}}\left(\mathrm{CS}-\mathrm{K}_{0.5}-\mathrm{B}_{0.5}^{\prime}\right)$ and $\mathrm{M}_{\mathrm{B}}\left(\mathrm{CS}-\mathrm{K}_{0.5}^{\prime}-\mathrm{B}_{0.5}\right)$ were obtained by the same method.

\section{Characterization of peptides. The CFFVLKG-PEG and CGGAAG-PEG were} confirmed by matrix-assisted laser desorption ionization time-of-flight mass spectrometry (MALDI-TOF-MS, Bruker Daltonics). The chemical structures of $\mathrm{M}_{1-5}, \mathrm{M}_{K}$, and $\mathrm{M}_{\mathrm{B}}$ were proven by NMR measurements. ${ }^{1} \mathrm{H}$ NMR spectra (400 $\mathrm{MHz}$ ) of the $\mathrm{M}_{1-5}, \mathrm{M}_{\mathrm{K}}$, and $\mathrm{M}_{\mathrm{B}}$ in $d^{6}-\mathrm{H}_{2} \mathrm{O}$ and Acryl-CS in $d^{6}$-DMSO were recorded on a Bruker ARX $400 \mathrm{MHz}$ spectrometer.

ThT fluorescence assay. The ThT fluorescence assay was recorded at $485 \mathrm{~nm}$ through microplate absorbance reader (Tecan infinite M200, Switzerland) with excitation wavelength of $450 \mathrm{~nm}$. For each measurement, the pre-treated $A \beta$ solutions with and without $\mathrm{M}_{1-5}, \mathrm{M}_{K}$, and $\mathrm{M}_{\mathrm{B}}$ were co-incubated with ThT solutions in phosphate buffer to the final concentration of $A \beta$ peptide at $20 \mu \mathrm{M}$, $\mathrm{M}_{1-5}, \mathrm{M}_{\mathrm{K}}$, and $\mathrm{M}_{\mathrm{B}}$ at $20 \mu \mathrm{g} \cdot \mathrm{mL}^{-1}$, ThT at $20 \mu \mathrm{M}$.

Circular dichroism (CD) spectra. The CD spectra of $A \beta\left(0.09 \mathrm{mg} \cdot \mathrm{mL}^{-1}, 20 \mu \mathrm{M}\right)$ with or without $\mathrm{M}_{3}, \mathrm{M}_{\mathrm{K}}$, and $\mathrm{M}_{\mathrm{B}}\left(20 \mu \mathrm{g} \cdot \mathrm{mL}^{-1}\right)$ were monitored using a $\mathrm{CD}$ spectrometer (JASCO-1500, Tokyo, Japan) with a cell path length of $1 \mathrm{~mm}$ at room temperature. The measurements were implemented between $190 \mathrm{~nm}$ to $280 \mathrm{~nm}$ with a resolution of $1.0 \mathrm{~nm}$ and a scanning speed of $300 \mathrm{~nm} \cdot$ minute $^{-1}$. For each measurement, 3 spectra were collected and averaged.

Transmission electron microscopy (TEM). The morphologies of $M_{3}, M_{K}$, and $M_{B}$ nanoparticles, $A \beta$ fibril and their mixture were observed by TEM (Tecnai G2 20 S-TWIN) with an acceleration voltage of $200 \mathrm{kV}$. The $\mathrm{M}_{3}, \mathrm{M}_{\mathrm{K}}$, and $\mathrm{M}_{\mathrm{B}}$ nanoparticle solutions were prepared by dispersing $5 \mathrm{mg} \cdot \mathrm{mL}^{-1}$ DMSO into PBS with a final concentration of $20 \mu \mathrm{g} \cdot \mathrm{mL}^{-1}$. The $\mathrm{A} \beta$ nanofibril $(20 \mu \mathrm{M})$ and the co-assembly solutions were obtained after incubating $24 \mathrm{~h}$ at $37^{\circ} \mathrm{C} .10 \mu \mathrm{L}$ of the solutions were dropped onto a copper mesh for $5 \mathrm{~min}$, subsequently removed most of the liquid through a filter paper. $10 \mu \mathrm{L}$ of uranyl acetate solution was employed to stain the samples for $5 \mathrm{~min}$, followed by drying the spare liquid with the filter. Finally, the copper mesh was washed with $10 \mu \mathrm{L}$ of deionized water, which was blotted after staining and dried at room temperature.

Cytotoxicity assay for mouse neuroblastoma N2a cells. Mouse neuroblastoma N2a cell line was purchased from cell culture center of Institute of Basic Medical Sciences, Chinese Academy of Medical Sciences (Beijing, China), and was utilized to evaluate the cytotoxicity of $M_{1-5}, M_{K}$, and $M_{B}$ nanoparticles by the CCK- 8 assay. A density of $5 \times 10^{3} \mathrm{~N} 2$ a cells per well were seeded in the 96-well plates in DMEM supplemented with $10 \%$ fetal bovine serum (FBS) and $1 \%$ penicillin-streptomycin in a humidified atmosphere with $5 \% \mathrm{CO}_{2}$ and then cultured at $37^{\circ} \mathrm{C}$ for a night. 10 $\mu \mathrm{L}$ of $\mathrm{M}_{1-5}, \mathrm{M}_{\mathrm{K}}$, and $\mathrm{M}_{\mathrm{B}}$ were dispersed in DMEM medium with a series of different concentrations, $10,20,50,100,200 \mu \mathrm{g} \cdot \mathrm{mL}^{-1}$ to obtain an optimal $\mathrm{M}_{1-5}$, $M_{K}$ and $M_{B}$ concentration. $A \beta$ at the concentration of $20 \mu \mathrm{M}$ with and without $\mathrm{M}_{1-5}, \mathrm{M}_{\mathrm{K}}$ and $\mathrm{M}_{\mathrm{B}}$ sample solutions were co-incubated with cells for additional 24 h. Subsequently, $10 \mu \mathrm{L}$ of CCK-8 solutions was added to each well and cultured for $4 \mathrm{~h}$. The UV-vis absorptions of sample wells $\left(\mathrm{A}_{\text {sample }}\right), \mathrm{A}_{\text {blank }}$ and control wells $\left(\mathrm{A}_{\text {control }}\right)$ were performed by a Microplate reader at a test wavelength of $450 \mathrm{~nm}$ and a reference wavelength of $690 \mathrm{~nm}$, respectively. Cell viability (\%) was equal to $\left(\mathrm{A}_{\text {sample }}-\mathrm{A}_{\text {blank }}\right) /\left(\mathrm{A}_{\text {control }}-\mathrm{A}_{\text {blank }}\right) \times 100 \%$. All the experiments were performed in triplicate. The cell lines had been authenticated utilizing short tandem repeat DNA profiling. All cells were tested negative for cross-contamination of other human cells and mycoplasma contamination.

Confocal laser scanning microscopy (CLSM) observation. The N2a cells incubated with and without $M_{3}, M_{K}$, and $M_{B}$ were investigated on a Zeiss LSM710 confocal laser scanning microscope (Jena, Germany). N2a cells were seeded in complete DMEM media in a humidified atmosphere with $5 \% \mathrm{CO}_{2}$ and then cultured at $37^{\circ} \mathrm{C}$ for a night. For co-localization analysis, the medium was replaced by $1 \mathrm{~mL}$ of serum free fresh medium containing $20 \mu \mathrm{g}\left(\mathrm{M}_{3}, \mathrm{M}_{\mathrm{K}}\right.$, and $\left.\mathrm{M}_{\mathrm{B}}\right)$ Cy5-labeled nanoparticles, $20 \mu \mathrm{M}$ FITC-labeled A $\beta$. Then the cell were cultured with the serum free fresh medium for another $2 \mathrm{~h}$ and washed with PBS for 3 times. After replacement of the medium with PBS, cells were imaged using a Zeiss LSM710 confocal laser scanning microscope with a $\times 63$ objective lens.
Western blotting analysis. N2a cells were treated with $M_{3}, M_{K}$ and $M_{B}(20 \mu g \cdot m L$ ${ }^{-1}$ ) for $12 \mathrm{~h}$, and then re-suspended lysis buffer solution with $1 \%(\mathrm{v} / \mathrm{v})$ Triton-X 100 in $150 \mathrm{mM} \mathrm{NaCl}$ and $50 \mathrm{mM}$ Tris- $\mathrm{HCl}(\mathrm{pH}=8.0)$. The protein content was estimated by a BCA kit (Applygen). Each sample ( $60 \mu \mathrm{g}$ of protein) was subjected to SDS-PAGE and then transferred to a nitrocellulose membrane. Blots were blocked in a blocking buffer containing $5 \%(\mathrm{wt} / \mathrm{v})$ non-fat milk, $0.1 \%(\mathrm{v} / \mathrm{v})$ Tween 20 in $0.01 \mathrm{M}$ TBS, and incubated with primary antibodies overnight at $4{ }^{\circ} \mathrm{C}$ and then incubated with an appropriate secondary antibody (ZSGB-BIO) for another hour at room temperature, subsequently scanned on a Typhoon Trio Variable Mode Imager. Band density was calculated using ImageJ software. The following antibodies were used: LC3B (AL221, 1:1000 dilution, Beyotime Institute of Biotechnology, China), $\beta$-actin (30101ES, 1:1000 dilution, Yeasen Biology Ltd., China) and p62 (5114, 1:1000 dilution, CST). Uncropped blots were presented in Supplementary Fig. 20.

Bio-TEM for autophagy in vivo. The part of brain from mice were first fixed overnight at $4{ }^{\circ} \mathrm{C}$ in PBS buffer with $2.5 \%$ glutaraldehyde. After washing with PBS buffer $(0.1 \mathrm{M})$ for three times, the brain tissues were fixed at room temperature with $1 \%$ osmium-containing PBS buffer for $2 \mathrm{~h}$. Subsequently, all the brain tissues were washed three times with PBS buffer and dehydrated with a graded series of acetone $(50,70,80,90,95,100 \%)$ for 15 min for each step. After infiltrated with a graded of series of mixtures (acetone/EPON 812 resin: 2/1, 1/1, 1/2) at room temperature for $1 \mathrm{~h}$, pure resin was added and incubated overnight at $4^{\circ} \mathrm{C}$. Finally, the gelatin capsules were used to cover the tissues and incubated with pure EPON 812 resin at 37,45 , and $60^{\circ} \mathrm{C}$ for $24 \mathrm{~h}$, respectively. The tissues were cut into ultrathin sections by a diamond knife and picked up with Formvar-coated copper grids ( 300 mesh). All of the sections were performed counter-staining with osmic acid (1\%) for $1 \mathrm{~h}$ and uranyl acetate $(4 \%)$ for $20 \mathrm{~min}$, respectively. JEOL JEM-1400 electron microscope (JEOL, Tokyo, Japan) was used to observe tissues.

Measurement of soluble and insoluble $\mathbf{A} \boldsymbol{\beta}_{\mathbf{4 2}}$ in the brain. Brain tissue (one brain hemisphere, 4 mice per group) for ELISAs was mechanically homogenized in 10 volumes of ice-cold guanidine buffer $\mathrm{pH} 8.0$ ) and were mixed for 3 to $4 \mathrm{~h}$ at room temperature (RT) as described ${ }^{42}$. Then diluted brain homogenates with $1: 10$ by icecold casein buffer $(0.25 \%$ casein $/ 0.05 \%$ sodium azidey $/ 20 \mathrm{mg} / \mathrm{mL}$ aprotininy $/ 5 \mathrm{mM}$ EDTA, $\mathrm{pH} 8.0 / 10 \mu \mathrm{g} / \mathrm{mL}$ leupeptin in PBS) was centrifuged $30 \mathrm{~min}$ at $4{ }^{\circ} \mathrm{C}$ for $16,000 \times \mathrm{g}$. The supernatant included $0.5 \mathrm{M}$ guanidine in the presence of $0.1 \%$ bovine serum albumin (BSA) was removed for ELISA measurement for soluble $\mathrm{A} \beta_{42}$ and $\mathrm{A} \beta_{\text {total }}$ or stored $-80^{\circ} \mathrm{C}$. The homogenate pellet that remains after centrifugation were added $425 \mu \mathrm{L}$ cold formic acid and kept tubes on ice. Each sample was sonicated on ice continuously until that the pellet dissolved. Then performed high-speed spin at $109,000 \times g$ for $1 \mathrm{~h}$ at $4{ }^{\circ} \mathrm{C}$ and took $105 \mu \mathrm{L}$ sample and add $1.895 \mathrm{~mL}$ of formic-acid neutralization buffer ( $1 \mathrm{M}$ Tris base $/ 0.5 \mathrm{M} \mathrm{Na}_{2} \mathrm{HPO}_{4} /$ $0.05 \% \mathrm{NaN}_{3}$ ) on ice for ELISA measurement for insoluble $\mathrm{A} \beta_{42}$ and $\mathrm{A} \beta_{\text {total }}$ or stored $-80^{\circ} \mathrm{C}$. Mouse $\mathrm{A} \beta_{1-42}$ ELISA Kit (R141671) and Mouse A $\beta$ ELISA Kit (R167250) from the Trust Specialty Zeal biological trade Co., Ltd., U.S.A. were used, respectively.

Morris water maze (MWM) experiment. Animal experiments were carried out complying with NIH guidelines for the Care and Use of Laboratory Animals, and the study the protocol was approved by the Institutional Animal Care and Use Committee of National Center for Nanoscience and Technology, China. All animals were obtained from Beijing HFK bioscience Co., Ltd. (Beijing, China). The non-Tg C57 mice were regarded as wild type mice (WT mice). The APPswe/ PS1dE9 transgenic mice (AD mice) were divided into two group, $\mathrm{AD}$ group and $\mathrm{M}_{3}$ group ( 3 mice per group). All mice were male, and 9 month old, which intravenously administered PBS and $\mathrm{M}_{3}$ nanoparticles, respectively. All mice were trained and tested in a water maze with a diameter of $1.1 \mathrm{~m}$. The maze was filled with water and drained daily. The temperature of the water was maintained at $22 \pm 1^{\circ} \mathrm{C}$. The platform $(0.1 \mathrm{~m}$ in diameter) was immobilized to $1 \mathrm{~cm}$ under the water surface during the training period, whereas the starting points were counter balanced. From the first day to the fourth day during training, the mice were measured four times from four diversed positions around the border of the maze in a semirandom order with $60 \mathrm{~s}$ latent period to reach the platform. If the animal find the hidden platform successfully within $60 \mathrm{~s}$, it was allowed to stay on the platform for $15 \mathrm{~s}$. If it failed to find the platform, the mice had to be placed on the platform for $15 \mathrm{~s}$. The motional orbits of each mice was recorded and studied using a computerized video-tracking system. When the last learning trial was finished, the memory capacity of each mice were explored by a probe trial without the platform. Every trained animal was allowed to swim freely for $60 \mathrm{~s}$, with two initial sites far away from the targeted platform. The time each mouse spent in searching for the platform in the quadrant where the platform used to be (target quadrant), and the number of times it crossed the target quadrant was recorded.

Immunohistochemical analysis and nissl staining. After the MWM test, the mice were euthanized. The tissue sections in the coronal plane at $40 \mu \mathrm{m}$ on a freezing sliding microtome from the genu of the corpus callosum through the caudal extent of the hippocampus ( $3 \mu \mathrm{m}$-thick, 4 sections/mouse, 3 mice/group). For qualitative 
analysis of $\mathrm{A} \beta$ immunoreactivity, half sections were immunostained as described ${ }^{43}$ with the following $A \beta$ antibodies: Rabbit Anti-beta-Amyloid 1-42 (CT antibody) (bs-0076R, 1:200, Bioss, Beijing, China) and Anti-rabbit IgG (H + L) A $\beta$ Hrp (074$1506,1: 200$, KPL, Massachusetts, USA). The sections were observed under a microscope (XSP-C204, COIC, China). Pictures were acquired with a digital camera and analyzed with the ImageJ software. The area occupied by $A \beta$ plaques was quantified as the percent surface area occupied in the delineated hippocampus. The plaques were quantified as the ratio of plaques vs corresponding hippocampal area and the detailed process was shown as follows: The ratio of plaques vs hippocampal area (R\%) was calculated based on $\mathrm{R} \%=\mathrm{S}_{\mathrm{t}} / \mathrm{S} \times 100 \%$. $\mathrm{S}_{\mathrm{t}}$ is the total area of plaques, and the $S_{t}=S_{1}+S_{2}+S_{3}+\ldots$, where the $S_{1}, S_{2}, S_{3} \ldots$ indicates the area of each plaques. $S$ is the analytical hippocampal area. For Nissl staining, half sections were stained with cresyl violet for Nissl body staining in the neurons. The sections were examined and photographed under a microscope (Nikon Eclipse E100) with DS-U3 DS Camera Control Unit. The number of staining cells was counted at $400 \times$ magnification in blinded manner, only structures of appropriate size and shape were demonstrated clearly. The final results were shown as mean \pm $\mathrm{SD}(n=6)$.

Statistical analysis. All data are reported as mean \pm standard deviation (s.d.). The in vitro experiments were performed in three independent experiments with at least three technical replicates. The in vivo experiments were performed with 3-4 mice for each group. Statistical analysis of the samples was performed using Student's t-test, and $\mathrm{P}$ value of $<0.05$ was considered significant.

Data availability. The data that support the findings of this study are available within the article, its Supplementary Information files and from the corresponding author upon reasonable request.

Received: 8 May 2017 Accepted: 18 April 2018

Published online: 04 May 2018

\section{References}

1. Mattson, M. P. Pathways towards and away from Alzheimer's disease. Nature 430, 631-639 (2004).

2. Marsh, S. E. et al. The adaptive immune system restrains Alzheimer's disease pathogenesis by modulating microglial function. Proc. Natl Acad. Sci. USA 113, 1316-1325 (2016).

3. Hindo, S. S. et al. Small molecule modulators of copper-induced $A \beta$ aggregation. J. Am. Chem. Soc. 131, 16663-16665 (2009).

4. Cavalli, A. et al. A small molecule targeting the multifactorial nature of Alzheimer's disease. Angew. Chem. Int. Ed. 46, 3689-3692 (2007).

5. Annaert, W. \& De Strooper, B. Alzheimer's disease neurons fail the acid test. Cell 141, 1112-1114 (2010).

6. Huang, F. et al. Maintenance of amyloid beta peptide homeostasis by artificial chaperones based on mixed-shell polymeric micelles. Angew. Chem. Int. Ed. 53, 8985-8990 (2014).

7. Canter, R. G., Penney, J. \& Tsai, L. H. The road to restoring neural circuits for the treatment of Alzheimer's disease. Nature 539, 187-196 (2016).

8. Geng, J., Li, M., Ren, J., Wang, E. \& Qu, X. Polyoxometalates as inhibitors of the aggregation of amyloid beta peptides associated with Alzheimer's disease. Angew. Chem. Int. Ed. 50, 4184-4188 (2011).

9. McLaurin, J. et al. Therapeutically effective antibodies against amyloid-beta peptide target amyloid-beta residues 4-10 and inhibit cytotoxicity and fibrillogenesis. Nat. Med. 8, 1263-1269 (2002).

10. Yovel, Y., Franz, M. O., Stilz, P. \& Schnitzler, H. U. Plant classification from bat-like echolocation signals. PLoS Comput. Biol. 4, e1000032 (2008).

11. Lansbury, P. T. \& Lashuel, H. A. A century-old debate on protein aggregation and neurodegeneration enters the clinic. Nature 443, 774-779 (2006).

12. Takahashi, T. \& Mihara, H. Peptide and protein mimetics inhibiting amyloid beta-peptide aggregation. Acc. Chem. Res. 41, 1309-1318 (2008).

13. Ehrnhoefer, D. E. et al. EGCG redirects amyloidogenic polypeptides into unstructured, off-pathway oligomers. Nat. Struct. Mol. Biol. 15, 558-566 (2008).

14. Kisilevsky, R. et al. Arresting amyloidosis in vivo using small-molecule anionic sulphonates or sulphates: implications for Alzheimer's disease. Nat. Med. 1, 143-148 (1995).

15. $\mathrm{Hu}, \mathrm{B}$. et al. Nanotheranostics: Congo Red/Rutin-MNPs with enhanced magnetic resonance imaging and $\mathrm{H}_{2} \mathrm{O}_{2}$-responsive therapy of Alzheimer's disease in APPswe/PS1dE9 transgenic mice. Adv. Mater. 27, 5499-5505 (2015).

16. Zhang, R. et al. Traceable nanoparticle delivery of small interfering RNA and retinoic acid with temporally release ability to control neural stem cell differentiation for Alzheimer's disease therapy. Adv. Mater. 28, 6345-6352 (2016).
17. Yoo, S. I. et al. Inhibition of amyloid peptide fibrillation by inorganic nanoparticles: functional similarities with proteins. Angew. Chem. Int. Ed. 50, 5110-5115 (2011)

18. Miles, L. A., Crespi, G. A. N., Doughty, L. \& Parker, M. W. Bapineuzumab captures the N-terminus of the Alzheimer's disease amyloid-beta peptide in a helical conformation. Sci. Rep. 3, 1302-1302 (2013).

19. Mccartney, M. Margaret McCartney: The "breakthrough" drug that's not been shown to help in Alzheimer's disease. BMJ 351, h4064 (2015).

20. Salloway, S. et al. Two phase 3 trials of bapineuzumab in mild-to-moderate Alzheimer's disease. N. Engl. J. Med. 370, 322-333 (2014).

21. Cummings, J. L., Morstorf, T. \& Zhong, K. Alzheimer's disease drugdevelopment pipeline: few candidates, frequent failures. Alzheimers Res. Ther. 6, 37 (2014).

22. Nixon, R. A. Autophagy, amyloidogenesis and Alzheimer disease. J. Cell. Sci. 120, 4081-4091 (2007).

23. Cai, Z. et al. Mammalian target of rapamycin: a valid therapeutic target through the autophagy pathway for Alzheimer's disease? J. Neurosci. Res. 90, 1105-1118 (2012).

24. Nixon, R. A. The role of autophagy in neurodegenerative disease. Nat. Med. 19, 983-997 (2013)

25. Sarkar, S. Role of autophagy in neurodegenerative diseases. Curr. Sci. 101, 514-519 (2011).

26. Qiao, Z. Y. et al. A general strategy for facile synthesis and in situ screening of self-assembled polymer-peptide nanomaterials. Adv. Mater. 28, 1859-1867 (2016).

27. Soto, C. et al. $\beta$-sheet breaker peptides inhibit fibrillogenesis in a rat brain model of amyloidosis: Implications for Alzheimer's therapy. Nat. Med. 4, 822-826 (1998).

28. Pallitto, M. M., Ghanta, J., Heinzelman, P., Kiessling, L. L. \& Murphy, R. M. Recognition sequence design for peptidyl modulators of beta-amyloid aggregation and toxicity. Biochemistry 38, 3570-3578 (1999).

29. Shoji-Kawata, S. et al. Identification of a candidate therapeutic autophagyinducing peptide. Nature 494, 201-206 (2013).

30. Wang, Y. et al. Self-assembled autophagy-inducing polymeric nanoparticles for breast cancer interference in-vivo. Adv. Mater. 27, 2627-2634 (2015).

31. Xie, H. et al. Inhibition of beta-amyloid peptide self-assembly and cytotoxicity by poly(LVFF-co-beta-amino ester). J. Pept. Sci. 21, 608-614 (2015).

32. Gao, N. et al. Transition-metal-substituted polyoxometalate derivatives as functional anti-amyloid agents for Alzheimer's disease. Nat. Commun. 5, 3422 (2014).

33. Klionsky, D. J. et al. Guidelines for the use and interpretation of assays for monitoring autophagy. Autophagy 8, 445-544 (2012).

34. Zoccarato, F., Cavallini, L. \& Alexandre, A. The $\mathrm{pH}-\mathrm{s}$ ensitive dye acridine orange as a tool to monitor exocytosis/endocytosis in synaptosomes. J. Neurochem. 72, 625-633 (1999).

35. Lin, Y. X. et al. An in situ intracellular self-assembly strategy for quantitatively and temporally monitoring autophagy. ACS Nano 11, 1826-1839 (2017).

36. Sun, L. Q. et al. Neuronic autophagy contributes to p-connexin 43 degradation in hippocampal astrocytes following traumatic brain injury in rats. Mol. Med. Rep. 11, 4419-4423 (2015).

37. Ruiz, R., Perezvillegas, E. M., Bachiller, S., Rosa, J. L. \& Armengol, J. A. HERC 1 ubiquitin ligase mutation affects neocortical, CA3 hippocampal and spinal cord projection neurons: an ultrastructural study. Front. Neuroanat. 10, 42 (2016).

38. Luzio, J. P., Pryor, P. R. \& Bright, N. A. Lysosomes: fusion and function. Nat. Rev. Mol. Cell. Biol. 8, 622-632 (2007).

39. Doze, P., Van Waarde, A., Elsinga, P. H., Hendrikse, N. H. \& Vaalburg, W. Enhanced cerebral uptake of receptor ligands by modulation of P-glycoprotein function in the blood-brain barrier. Synapse 36, 66-74 (2000).

40. Hendrikse, N. H. et al. Complete in vivo reversal of P-glycoprotein pump function in the blood-brain barrier visualized with positron emission tomography. Br. J. Pharmac. 124, 1413-1418 (1998).

41. Song, Q. et al. Lipoprotein-based nanoparticles rescue the memory loss of mice with Alzheimer's disease by accelerating the clearance of amyloid-beta. ACS Nano 8, 2345-2359 (2014).

42. JohnsonWood, K. et al. Amyloid precursor protein processing and A beta(42) deposition in a transgenic mouse model of Alzheimer disease. Proc. Natl Acad. Sci. USA 94, 1550-1555 (1997).

43. Sun, Y. L. et al. Glial fibrillary acidic protein-apolipoprotein E (apoE) transgenic mice: astrocyte-specific expression and differing biological effects of astrocyte-secreted apoE3 and apoE4 lipoproteins. J. Neurosci. 18, 3261-3272 (1998).

\section{Acknowledgements}

This work was supported by the National Natural Science Foundation of China (21374026, 51573032, 51573031), the National Science Fund for Distinguished Young Scholars (51725302), Science Fund for Creative Research Groups of the National Natural Science Foundation of China (11621505), and CAS Key Research Program for Frontier 
Sciences (QYZDJ-SSW-SLH022). Key Project of Chinese Academy of Sciences in Cooperation with Foreign Enterprises (GJHZ1541) and, CAS Interdisciplinary Innovation Team, Jilin Province Key Laboratory of Organic Functional Molecular Design and Synthesis (No. 130028649).

\section{Author contributions}

Q. L., Y.-X. L., J.-P. Z., L. W., and H. W. conceived the project and wrote the manuscript. Q. L., Y.-X. L., Y. W., J.-P. Z., L. W., and H. W. planned and designed experiments. Q. L., Y.-X. L., P.-P. Y., Y. W., G.-B. Q. B.-N. L., K. Z., and Z.-Y. Q. performed experiments. Q. L., Y.-X. L., and P.-P. Y. contributed equally to this work.

\section{Additional information}

Supplementary Information accompanies this paper at https://doi.org/10.1038/s41467018-04255-Z.

Competing interests: The authors declare no competing interests.

Reprints and permission information is available online at http://npg.nature.com/ reprintsandpermissions/
Publisher's note: Springer Nature remains neutral with regard to jurisdictional claims in published maps and institutional affiliations.

\section{(c) (i)}

Open Access This article is licensed under a Creative Commons Attribution 4.0 International License, which permits use, sharing, adaptation, distribution and reproduction in any medium or format, as long as you give appropriate credit to the original author(s) and the source, provide a link to the Creative Commons license, and indicate if changes were made. The images or other third party material in this article are included in the article's Creative Commons license, unless indicated otherwise in a credit line to the material. If material is not included in the article's Creative Commons license and your intended use is not permitted by statutory regulation or exceeds the permitted use, you will need to obtain permission directly from the copyright holder. To view a copy of this license, visit http://creativecommons.org/ licenses/by/4.0/.

(C) The Author(s) 2018 